Environmental Modeling \& Assessment

June 2018, Volume 23, Issue 3, Pages 203-227

http://dx.doi.org/10.1007/s10666-017-9580-4

http://archimer.ifremer.fr/doc/00405/51674/

(C) Springer International Publishing AG 2017

\title{
Can Offshore Wind Energy Be a Lever for Job Creation in France? Some Insights from a Local Case Study
}

\author{
Kahouli Sondès ${ }^{1,{ }^{*}}$, Martin Jean Christophe ${ }^{2}$ \\ ${ }^{1}$ Université de Bretagne OccidentaleUMR AMUREBrest Cedex 3, France \\ ${ }^{2}$ Ifremer, Unité d'Economie Maritime UMR 6308 AMUREPlouzané, France \\ *Corresponding author : Sondès Kahouli, email address : sondes.kahouli@univ-brest.fr
}

\begin{abstract}
:
The French government has launched three separate calls for tender in July 2011, March 2013, and December 2016 to install $3.5 \mathrm{GW}$ of offshore wind. In addition to contributing to the fulfillment of environmental commitments, the deployment of offshore wind energy is expected to be a lever for economic development. To assess gross economic impacts, mainly in terms of job creation, we built a regional input-output model of the wind farm off Saint-Brieuc located in the region of Brittany, northwestern France. Our model indicates that the project will have positive effects on Brittany's economy. In particular, during the investment phase, the wind farm is expected to lead to $€ 0.38 \mathrm{M} / \mathrm{year} / \mathrm{MW}$ of added value and 6.03 full-time equivalent (FTE) jobs/year/MW. During the operation and maintenance (O\&M) phase, the model predicts the generation of $€ 0.15 \mathrm{M} / \mathrm{year} / \mathrm{MW}$ of added value and $1.02 \mathrm{FTE}$ jobs/year/MW. These results imply that the project will increase Brittany's GDP slightly by 0.22 and $0.09 \%$ during the investment and O\&M phases, respectively. Results also show that out of total wealth created in France, 38 and $66 \%$ will be created in Brittany as well as 32 and $51 \%$ of employment during respectively investment and O\&M phases. A comparative analysis highlights in particular that economic impacts are generally stronger during the investment phase. It also demonstrates that the magnitude of economic impacts depends on the proportion of local industries in the supply chain. Policy implications of our model stress the need to revise the economic, technological, regulatory, and social frameworks within which the offshore wind industry currently operates in France to establish the conditions necessary for its development.
\end{abstract}

Keywords : Offshore wind, Economic impacts, input-output model, France

JEL Classification

Q42 Q43 D57 R15 


\section{$1 \quad 1$ Introduction}

In 2008, the European Union (EU) adopted the so-called climate and energy package, targeting a 20\% reduction in its greenhouse gas emissions by 2020 (with respect to 1990 levels) as well as a 20\% increase in its energy efficiency and a $20 \%$ share of renewable energy in total energy consumption. Along the same lines, in early 2014, it proposed a new policy framework for 2030, supporting and extending the 2020 climate and energy package. In particular, by 2030, the EU aims to reduce domestic greenhouse gas emissions by $40 \%$ below 1990 levels, improve energy efficiency by $30 \%$ and reach a share of renewable energy of at least $27 \%$ in total energy consumption.

To increase the share of renewable energy in the total energy consumption as defined by the EU, the French government decided in 2008 as part of the Grenelle Forum on the Environment (Grenelle de l'environnement) to increase the share of renewable energy in total energy consumption to $23 \%$ by 2020 (MEEDM, 2010). In particular, since France possesses $3500 \mathrm{~km}$ of coastline, four maritime seaboards and the second highest wind energy potential in Europe, it was decided within the framework of the Grenelle Forum on Maritime Policy (Grenelle de la mer) to target the development of $6 \mathrm{GW}$ of marine renewable energy by 2020, based mainly on offshore wind.

In July 2011, the French government launched the first call for tender for $3 \mathrm{GW}$ of offshore wind in five areas located off Dieppe-Le Tréport (Seine-Maritime département, 750 MW), Fécamp (Seine-Maritime, $500 \mathrm{MW}$ ), Courseulles-sur-mer (Calvados département, $500 \mathrm{MW}$ ), Saint-Nazaire (Loire-Atlantique département, $750 \mathrm{MW}$ ) and Saint-Brieuc (Côtes d'Armor département, $500 \mathrm{MW}$ ). The project off Dieppe-Le Tréport (Seine-Maritime, 750 MW) was the only unsuccessful tender. In March 2013, a second call for tender was announced for an additional $1 \mathrm{GW}$ of offshore wind off Dieppe-Le Tréport (Seine-Maritime, $500 \mathrm{MW}$ ) and Noirmoutier (Vendée département, $500 \mathrm{MW}$ ). More recently in December 2016, the the third call for tender for $500 \mathrm{MW}$ of offshore wind in Dunkerque (Nord département) was launched ( $C f$. Figure 1).

In addition to contributing to the fulfilment of environmental commitments, the deployment of offshore wind energy is also expected to be a new lever for local and national economic development in France. Here, we build a regional input-output (I-O) model to assess the gross economic impacts of the project of Saint-Brieuc, a small town in the region of Brittany. This project is expected to enhance regional power production from renewable sources and create new employment opportunities (Iberdrola and Eole-Res, 2012b).

Brittany is characterized by a electricity supply-demand deficit with possible supply interruption in periods of peak demand during the winter. For the period from 2000 to 2012 , consumption increased by $22.21 \%$ in Brittany compared with only $11.9 \%$ on the national level (Eurostat, 2014a). During the same time period, although regional electricity production coming mainly from renewable sources has increased by $134 \%$, it covered no more than $11.8 \%$ of Brittany's electricity needs 3 (see Figure 2). This situation highlights

3. For example, in 2012, Brittany imported $29.9 \%$ of its electricity needs from the Cordemais thermal power station (Loire-Atlantique region) and about $70 \%$ from the Flamanville (Normandy region) and Chinon (Centre region) nuclear power plants. 


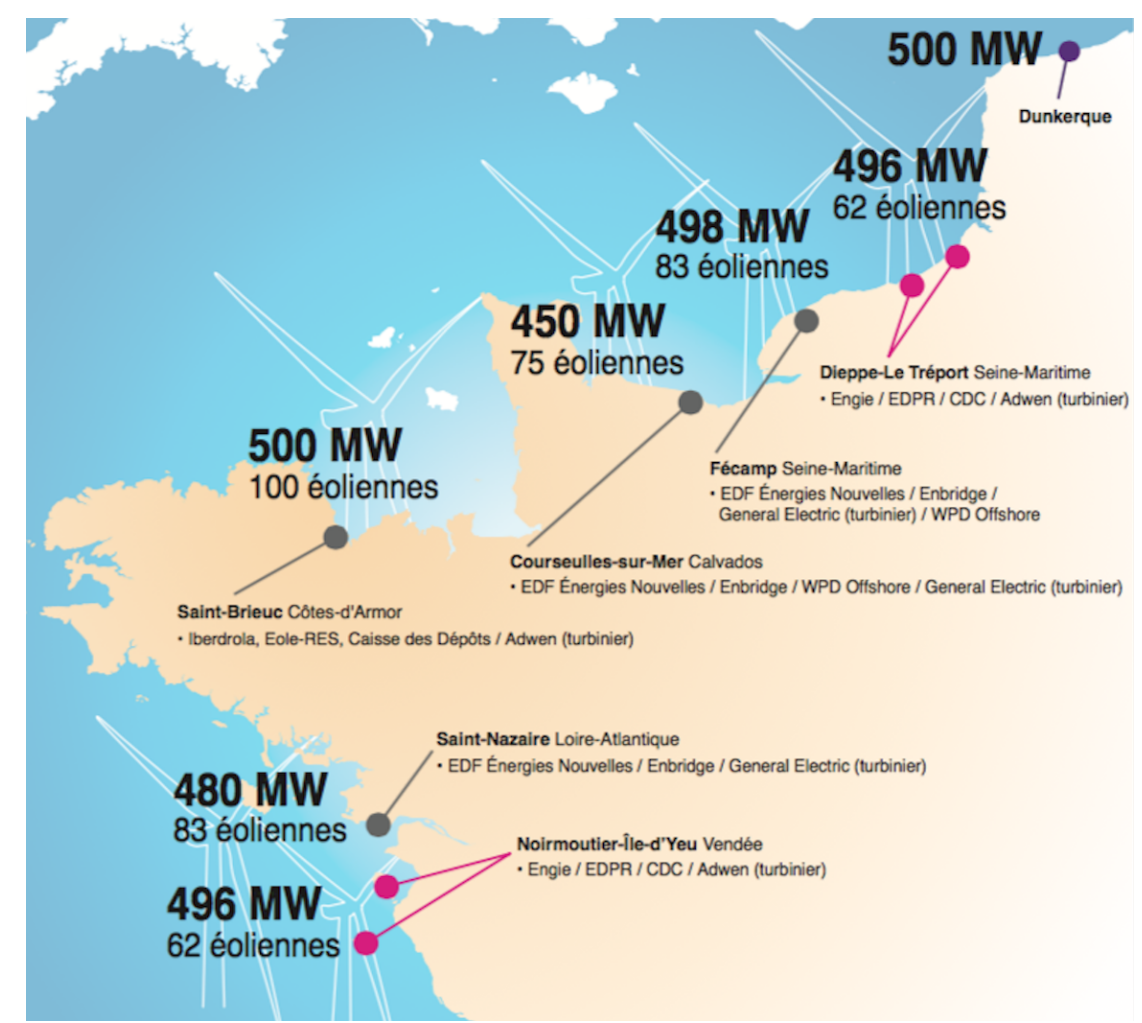

Figure 1. Offshore wind zones involved in French public calls for tender (the first round in gray, the second in pink, and the third in purple). Source: Observe-ER 2017

40 the importance of the Saint-Brieuc offshore wind project because, with an installed capac41 ity of $500 \mathrm{MW}$, it is expected to satisfy about $7 \%$ of the total electricity consumption of 42 Brittany.

Although the project clearly plays a role in supporting local energy production, in

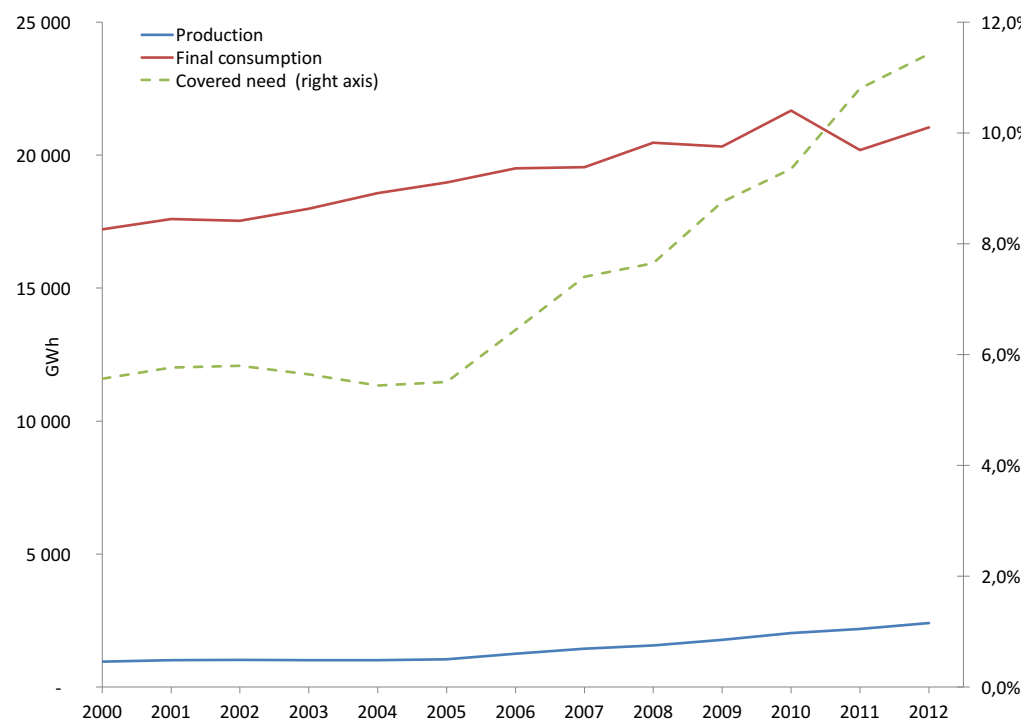

Figure 2. Production of electricity (GWh), Consumption of electricity (GWh), and covered needs, i.e. the share of local electricity production in total electricity consumption (\%)

44 this paper, we will focus on analysing its expected economic impacts mainly in terms of

45 job creation. The literature contains a number of papers studying the employment im- 
pacts of renewable energies (Hillebrand et al. (2006), Neuwahl et al. (2008), Blanco and Rodrigues (2009), Tourkolias and Mirasgedis (2011), Lambert and Silva (2012), GarrettPeltier (2017)). However, to our knowledge, this article is the first study to focus on the case of offshore wind farms in France.

We examine economic production, gross added value and full-time equivalent (FTE) jobs to measure the magnitude of expected regional economic impacts. We distinguish between direct, indirect, and induced impacts. Direct impacts take place within the industries immediately involved in the project during the development, construction, installation, and operation and maintenance (O\&M) phases. Indirect impacts cover the changes in interindustry trade as businesses respond to the new demand brought on by upstream offshore wind activities. Induced impacts measure the growth in economic activity due to increases in income, and therefore consumer spending, of employees/households. We calculate expected economic impacts for the two [most important] phases of the project namely the investment (i.e. construction and installation) and the O\&M phases.

The paper is structured as follows. In section 2, we present the Saint-Brieuc offshore wind project and its expected regional economic impacts. In section 3 , we present the methodology and data. In section 4 , we discuss our results based on a thorough comparative analysis. Finally, in section 5 , we conclude and detail some policy implications.

\section{Presentation of the project and its expected economic im- pacts}

The Saint-Brieuc offshore wind project is conducted jointly by Iberdrola and Eole-Res SA, which respectively hold a $70 \%$ and $30 \%$ stake in the project (together, Iberdrola and Eole-Res SA represent the Ailes Marines SAS consortium). This collaboration includes the development, construction, and operation of the farm. In the Saint-Brieuc project, 62 turbines rated at $8 \mathrm{MW}$ and reaching $215 \mathrm{~m}$ in height for a total of $496 \mathrm{MW}$ will be installed. The project is financed by the private sector. Its total investment cost is estimated at $€ 2 \mathrm{~B}{ }^{4}$ divided into two parts: capital expenditures (CAPEX) and operation expenditures (OPEX). CAPEX represent 70 to $75 \%$ of the total cost and OPEX 25 to $30 \%$. This investment cost is broken down into several items of expenditures as shown in Table 1 (Iberdrola and Eole-Res (2012b), Ailes Marines SAS (2014a)). Ailes Marines SAS estimates that the project will satisfy the annual electricity consumption of 840,000 habitants (Ouest France, 2014).

According to Ailes Marines SAS (2013a, 2014b), the project will require 7 years, from 2013 to 2020, to be completed, with the development phase ending in 2016. The development phase focused on analysing the technical and environmental characteristics of the project as well as on performing impact studies. From 2017 to 2020, construction and installation will be carried out. It is expected that the farm will be operational by late 2020. It will be operated for 20 years from 2020 to 2040 before being dismantled 5 .

4. This estimate does not include the cost of connecting the farm to the mainland grid.

5. For details on the schedule of the project, interested readers can consult Ailes Marines SAS (2014b). In addition, some technical characteristics of the project are presented in Appendix B 
Table 1 - Cost breakdown of the Saint-Brieuc offshore wind project (\%) Ailes Marines SAS, 2014a)

\begin{tabular}{ll}
\hline Task & Proportion of total cost (\%) \\
\hline Turbine system & $47 \%$ \\
Foundations & $37 \%$ \\
Inter-turbine cable & $5 \%$ \\
Offshore electric substation & $4 \%$ \\
Studies and consulting & $5 \%$ \\
Other & $2 \%$ \\
\hline Total & $100 \%$ \\
\hline
\end{tabular}

The project is expected to enhance the development of the French offshore wind industry. Although there currently is no well-established offshore wind industry in France, some components will be locally manufactured and several companies located mainly in north-western France ${ }^{6}$ will participate in the manufacture of 3600 turbine components (Ailes Marines SAS, 2014d). In this context, a directory of companies that may potentially participate in the Saint-Brieuc project was prepared by the Bretagne Pôle Naval cluster, through which 71 companies were identified $(\overline{\mathrm{BPN}}(2011, \overline{2012}))$.

Moreover, it is expected that two ports will be fitted out in Brittany. For manufacturing the electric substation and jacket foundations, Ailes Marines SAS decided to install factories in the port of Brest in the Finistere département because it is the only port in Brittany suitable for such operations. In fact, in addition to being easily accessible from the sea, by land and by rail, it has a high available storage capacity (CCICA, 2011). For maintenance activities, the port of Saint-Quay-Portrieux in Côtes d'Armor near the SaintBrieuc offshore farm has been selected and will be set up to reduce transportation costs and any delays.

Furthermore, it is also expected that the development of the Saint-Brieuc project will engender positive impacts on some economic activities that are not directly related to the offshore wind sector. For instance, during the construction phase, the project may enhance hotel and restaurant activities, particularly if an onshore base is considered for the construction stage (MEDDE, 2012b). Similarly, during the O\&M phase, tourism may be stimulated, because the region already has many attractive features (CCICA, 2011).

\section{Methodology and data}

This section aims to present the methodology that we used to estimate the economic impacts of the Saint-Brieuc offshore wind project. In particular, in subsection 3.1, we provide arguments supporting the relevance of using an I-O model. In subsection 3.2 , we present the main methodological aspects dealing with the calculation of regional economic impacts using an I-O model. Finally, in subsection 3.3, we detail the data and assumptions that we made to model offshore wind impacts during the investment and O\&M phases.

6. Also called the Grand-Ouest français, this area is not clearly defined and does not correspond to any administrative division, but covers the Brittany, Normandy and Pays-de-la-Loire regions and sometimes also includes the northern part of the Nouvelle-Aquitaine region as well as the Indre-et-Loire and Loir-etCher départements (both part of the Centre region). 


\subsection{The relevance of the I-O model for our impact studies}

Table C.1 in Appendix C provides a literature review dealing with the methodologies most widely used to assess the economic impacts of renewable energy technologies. It revealed two frequently used methodologies. The first is based on macro-economic modelling exercises using I-O tables, calculable general equilibrium (CGE), and macro-econometric (M-E) models. In some cases, econometric regressions are also used. The second methodology, referred to as analytical methodology, is based on surveys and other written information, i.e. data collection based on interviews, company annual reports, official tax-related business registers and government statistics ( bert and Silva (2012) $)^{7}$

After considering the advantages and drawbacks of the methodologies, we chose the I-O model to assess the economic impacts of the Saint-Brieuc offshore wind project. Although it has limitations, we believe that it provides the best trade-off between the aim of our study, the robustness of expected results, and the specific constraints inherent to the regional scale of the study as well as the specificities of the framework within which the offshore wind industry is currently emerging in France.

More precisely, we used an I-O model for five main reasons:

- We do not aim to focus only on impacts on the industrial component of the offshore wind sector, i.e. a bottom-up approach, but we also strive to analyse the impacts of the expansion of this sector on the economy, i.e. a top-down approach.

- CGE and M-E models require more detailed information than I-O models, and are generally applied at higher aggregated levels, i.e. European or national. Their application to regional studies is still very limited.

- I-O models are more accessible than CGE and M-E models which generally require a large and sometimes multidisciplinary research team. National I-O models constructed by the National Institute for Statistics and Economic Studies 8 are publicly available. Employing regionalization techniques, we were able to conduct a regional study 9 ,

- We aim to assess direct, indirect, and induced impacts, particularly employment impacts. The I-O model is more suitable than analytical methods, which generally

7. Comparisons of different macro-economic models are well-documented in the literature (Zhang and Folmer (1998), Madlener and Koller (2007), Miller and Blair (2009), Slattery et al. (2011), Lambert and Silva (2012), Brown et al. (2012)). Likewise, analytical modelling methodologies have been amply described (Weisberg et al. (1996), Schuman and Stanley (1996), Blanco and Rodrigues (2009), (EWEA, 2009a), Sastresa et al. (2010)). Therefore, we summarize only the most important studies focusing on energy impact assessments using these methodologies in Appendix C

8. Institut National de la Statistiques et des Études Économiques (INSEE).

9. Brown et al. (2012) analysed the robustness of I-O model results by comparing their results with those drawn from an ex post econometric analysis of economic impacts of wind power development in US counties. They showed that I-O models provide a good assessment of economic impacts despite its limitations. 
- Given the emergent nature of the offshore wind industry in France and its fragmented supply chain, we could not use analytical methods, in particular surveys. Surveys require clear identification of appropriate participants who will be contacted to complete questionnaires. Moreover, observing the controversial framework within which the offshore wind industry is currently emerging in France, we doubt that the response rate would be sufficient for drawing a reliable conclusion.

For these reasons, we used an I-O model for our regional impact analysis of the SaintBrieuc offshore wind project.

As discussed in Miller and Blair (2009), two types of I-O models can be constructed for regional studies: a single-region model and multi-region model, based either on an interregional approach or on a multi-regional approach. From a theoretical point of view, the multi-region model allows for a more detailed analysis because it identifies the geographical origin of impacts by incorporating inter-regional feedback. However, because this type of model is based on an established regional accounting system which does not exist in France, we can only use a single-region model.

\subsection{Methodological aspects of the calculation of economic impacts}

Based on Appendix D, we explain below the calculations of direct, indirect, and induced impacts (subsection 3.2.1) at a regional scale (subsection 3.2.2). The magnitude of these impacts is determined by four key factors:

- The size (or the cost) of the project. The bigger the project, the higher the value of the final induced demand is, and the higher the impacts of the project are.

- The share of industry production devoted to buying intermediate products. An increase in the value of technical coefficients leads to an increase in indirect impacts.

- The regional import rate indicating the proportion of imports of intermediate and final products. The regional import rate of a region is inversely proportional to regional technical coefficients, and to indirect and induced impacts.

- The share of employee wages in the production value of industries affected by the project. The share of employee wages in the production value is directly proportional to the induced impacts.

\subsubsection{Brief background on how to calculate economic impacts using I-O mod- els}

Direct impacts take place inside the industries directly involved in the project during the investment and O\&M phases 10

10. Several industries are directly involved in the project, depending on the phase (see subsection 3.3.2. Nonetheless, the main difficulties in calculating direct impacts is the attribution of costs/expenditures to the industries involved according to the activity nomenclature adopted by the French National Institute for Statistics and Economic Studies (INSEE). 
We assume that $X^{d i}, V^{d i}$, and $L^{d i}$ respectively represent the $n$-vectors of economic 183 production, added value and labour in the industries directly involved in the project.

184 Direct impact on economic production corresponds to the production value of the industries 185 directly affected by the change in the final demand induced by the project. According to 186 the supply-demand equilibrium, the value of this economic production $X$ should be equal 187 to the value of the change in final demand, $Y^{*}$. Thus,

$$
X^{d i}=Y^{*}
$$

By knowing respectively the $n$-vector of added value per unit of economic production $189 v$ and the $n$-vector of labour intensity corresponding to the quantity of labour required 190 to produce one monetary unit of production $l$, we can calculate the direct impacts of the 191 project in terms of added value and quantity of labour as follows:

$$
\begin{gathered}
V^{d i}=\hat{v} X^{d i} ; \\
L^{d i}=\hat{l} X^{d i},
\end{gathered}
$$

192 where the caret indicates that the matrix is diagonal.

193 Indirect impacts represent changes in inter-industry purchases as they respond to the 194 new demand induced by upstream offshore wind activities. In other words, indirect im195 pacts are the changes affecting the various industries of the economy directly and indirectly providing goods and services to industries directly involved in the project.

197 We assume that $X^{i n d i}, V^{i n d i}$, and $L^{i n d i}$ respectively represent the $n$-vectors of produc198 tion, added value and labour of industries indirectly involved in the project. By knowing 199 the production process of all industries, new industries included, and the final demand 200 inherent to the project, $Y^{*}$, we can calculate the sum of direct and indirect impacts on the 201 economic production as follows:

$$
X^{\text {dir+indi }}=(I-A)^{-1} Y^{*}=B Y^{*},
$$

202 where $I$ is the identity matrix, $A$ the matrix of technical coefficients, and $B=(I-A)^{-1}$ 203 the inverse Leontief matrix.

204 Likewise, the direct and indirect impacts on added value and labour, respectively, are 205 calculated as follows:

$$
\begin{array}{r}
V^{d i r+i n d i}=\hat{v}(I-A)^{-1} Y^{*}=\hat{v} B Y^{*} \\
L^{d i r+i n d i}=\hat{l}(I-A)^{-1} Y^{*}=\hat{l} B Y^{*}
\end{array}
$$


207 and indirect impacts and the direct impacts:

$$
\begin{gathered}
X^{i n d i}=X^{d i r+i n d i}-X^{d i r} ; \\
V^{i n d i}=V^{d i r+i n d i}-V^{d i r} ; \\
L^{i n d i}=L^{d i r+i n d i}-L^{d i r} .
\end{gathered}
$$

208 Induced impacts typically measure the growth in economic activity due to the increase 209 in incomes and therefore consumer spending of employees/households. The increase af210 fecting household incomes is engendered by the increase in economic production induced 211 by the project.

212 We assume that $X^{i n d u}, V^{i n d u}$, and $L^{i n d u}$ respectively represent the $n$-vectors of pro213 duction, added value and labour within industries due to induced impacts. These impacts 214 are calculated by extending the matrix of technical coefficients to household sectors $\bar{A}$. 215 When applying the closed Leontief model (1986) as detailed in Appendix D, the sum of 216 direct, indirect, and induced impacts for production is equal to

$$
X^{d i r+i n d i+i n d u}=(I-\bar{A})^{-1} Y^{*}=\bar{B} Y^{*}
$$

217 Similarly, the sum of direct, indirect, and induced impacts respectively on added value 218 and labour are calculated as follows:

$$
\begin{gathered}
V^{d i r+i n d i+i n d u}=\hat{v}(I-\bar{A})^{-1} Y^{*}=\hat{v} \bar{B} Y^{*} \\
L^{d i r+i n d i+i n d u}=\hat{l}(I-\bar{A})^{-1} Y^{*}=\tilde{l} \bar{B} Y^{*}
\end{gathered}
$$

219 We therefore deduce induced impacts as the difference between the sum of all impacts, 220 i.e. direct, indirect, and induced, and the sum of direct and indirect impacts:

$$
\begin{gathered}
X^{i n d u}=X^{d i r+i n d i+i n d u}-X^{d i r+i n d i} \\
V^{i n d u}=V^{d i r+i n d i+i n d u}-V^{d i r+i n d i} \\
L^{i n d u}=L^{d i r+i n d i+i n d u}-L^{d i r+i n d i}
\end{gathered}
$$

221 We calculated direct, indirect, and induced gross impacts for the investment and O\&M 222 phases.

\section{$223 \quad 3.2 .2$ Adaptation of the I-O model to the regional scale}

France has not developed a regional accounting system; we therefore regionalized the 225 French national I-O table as detailed below to analyse regional impacts.

226 We calculated regional technical coefficients by subtracting imports from the technical 227 coefficients (Round, 1978):

$$
a_{i j}^{R}=\left(1-m_{i j}\right) a_{i j}
$$


where $a_{i j}^{R}$ represents regional technical coefficients of industry $j$ for input $i, a_{i j}$ technical coefficients of industry $j$ for input $i$, and $m_{i j}$ the import rate indicating the proportion of input $i$ consumed by industry $j$ established outside of Brittany.

The import rate incorporates national import rates $m_{i j}^{N}$ representing inputs produced outside of France and regional import rates $m_{i j}^{R}$ indicating inputs produced in France but outside of Brittany:

$$
m_{i j}=m_{i j}^{N}+m_{i j}^{R}
$$

National import rates $m_{i j}^{N}$ are assumed to be stable within France regardless of the region. They were calculated directly from the national I-O table as follows:

$$
a_{i j}^{N}=\left(1-m_{i j}^{N}\right) a_{i j}
$$

where $a_{i j}^{N}$ represent national technical coefficients of industry $j$ for input $i$.

Several studies have focused on the estimation of regional import rates $m_{i j}^{R}$ to compensate for the lack of data on inter-regional trade. For instance, Leontief and Strout (1963) developed the gravity model to estimate the trade of products between different regions. Although this method is more satisfactory from a theoretical point of view, it is difficult to implement. An alternative method calls for the use of location quotients to estimate regional technical coefficients (Miller and Blair, 2009). The most frequently used location quotient in the literature is the simple location quotient $(S L Q)$. Nevertheless, one of its shortcomings is that the import rate is only determined by the relative sizes of selling sector $i$ and the study region. In this context, several studies dealing with the construction of regional I-O tables have developed $S L Q \mathrm{~s}$ by calculating weighted location quotients $(W L Q)$ leading to more reliable estimations of import rates. For instance, based on Round (1978), Flegg et al. (1995) and Flegg and Webber (1997) worked out a location quotient commonly noted as $F L Q$, which takes into account the relative size of selling sectors $i$, the relative size of buying sectors $j$, and the size of the region. Several empirical studies have shown that $F L Q$ provides a more accurate estimation of the import rate 11 . Flegg and Webber (1997) start with cross-industry location quotient $\left(C I L Q_{i j}\right)$, taking into account both the size of selling sectors $i$ relative to the size of buying sectors $j$ and the size of the region relative to the size of the nation $\lambda$. Therefore, they calculate the location quotient as

$$
F L Q_{i j}=C I L Q_{i j} \lambda \text { with } \lambda=\left(\log _{2}\left[1+\frac{V^{R}}{V^{N}}\right]\right)^{\delta},
$$

where $V^{R}$ and $V^{N}$ respectively represent the total added value of the region and the nation.

Flegg and Webber (1997) suggest estimating $\delta$ by using an econometric tool. In case of inadequate regional data, as in our case, they recommend setting $\delta$ to 0.3 . Regional

11. It primarily reduces estimation errors $($ Tohmo (2004), Flegg and Tohmo (2008), Bonfiglio and Chelli (2008)). 
technical coefficients were therefore calculated by using the following equation:

$$
a_{i j}^{R}=\left\{\begin{array}{r}
a_{i j}^{N} \text { if } F L Q_{i j} \geq 1 \\
a_{i j}^{N}\left(F L Q_{i j}\right) \text { if } F L Q_{i j}<1
\end{array}\right.
$$

\subsection{Data and assumptions}

In subsection 3.3.1, we give a general description of the required database and the I-O method that we used. In subsections 3.3 .2 and 3.3.3, we detail the data and assumptions regarding, respectively, the investment and O\&M phases for the simulation of the impacts of the project.

\subsubsection{Preliminary methodological presentation}

The database of the I-O model is the I-O table, which describes the origin and destination of products $i$ (with $i=1 \ldots n$ ) and the production process in industry $j$ (with $j=1 \ldots n)$. We consider a symmetrical I-O table in which each industry is assumed to produce only one product. Therefore, the number of products is equal to the number of industries, that is $n$, and the production of product $i$ is equal to the production of industry $j$ when $i=j$. The I-O table is used to calculate the matrix of technical coefficients $A$ indicating the goods and services needed to produce one monetary unit per industry. In addition, the I-O table estimates the vector of the final demand $Y$ for a given year.

We use the French I-O table for the year 2010 (Eurostat, 2014b which is symmetrical ${ }^{12}$ and broke down into 64 industries and products according to the statistical Classification of Products of Activity 2008 (CPA 2008). The values of domestic and imported commodities consumed by institutional agents within an economy are indicated in this I-O table.

A number of articles have used I-O models to assess the economic impacts of renewable energies (Pollin et al. (2008), Collins et al. (2012), Lambert and Silva (2012), Lehr et al. (2012), Markaki et al. (2013), Oliveira et al. (2013)). Two I-O approaches are generally used, either the "final-demand approach" or the "complete inclusion in the technical coefficients matrix" (Miller and Blair (2009)). The first approach considers the intermediate inputs consumed by the new industry as an exogenous change. They are recorded in the model as the final demand. In contrast, the second approach seeks to integrate the new industry in the technical coefficient matrix. Within the framework of the deployment of renewable energies, the second approach requires estimating the share of new renewable energy electricity consumed by regional industries and assessing how it affects the share of electricity coming from conventional energy sources consumed by the same regional industries.

The first approach has been widely used to estimate the economic impacts of renewable energy where their development is assumed to have no effect on the pattern of inputs used by other sectors and do not involve an offsetting constraint on the output of any sector

12. Eurostat (2014b) provides a symmetrical I-O table because it publishes both the use and the make matrices. For more information with regard to the construction of this symmetrical I-O table, interested readers can consult Eurostat (2008). 
290 proach has also been used in the literature to study the consequences of renewable energy 291 deployment. For instance, Garrett-Peltier (2017) use it to compare the employment effects 292 of renewable energy and and fossil fuels. In general, the second approach is more suitable 293 when the production of the new industry aims to substitute for the production of other 294 industries.

295 Here, we use the "final-demand approach". We assume that the construction of an off296 shore wind farm will not affect the pattern of inputs used by other sectors in the Brittany 297 region. Moreover, we know that the development of offshore wind energy in Brittany does 298 not aim to replace the production of electricity coming from conventional fuels, but to 299 supplement it. We calculated the technical coefficients $a_{i j}$ and the national technical co300 efficients $a_{i j}^{N}$. By using equation 19 , we also estimated the inter-regional trade to obtain 301 the regional technical coefficients $a_{i j}^{R}$ to calculate regional indirect and induced impacts. 302 However, the implementation of this equation requires knowing the regional added value 303 of industries. Because France has a poor regional accounting system, this regional added 304 value was calculated as the pro-rata number of employees in the region relative to the coun305 try for each industry by assuming that labour productivity is relatively similar between 306 Brittany and France 13 .

307 Calculating induced impacts requires knowing the share that employee wages account 308 for in the production for each industry and the share of household consumption in total 309 employee wages for each product. These data are not available at a regional scale, but we 310 assume that the proportion of wages in production as well as the consumption pattern of 311 households are similar for Brittany and France.

\subsubsection{The investment phase: creating the vector of demand to model the impacts of offshore wind 14}

To calculate direct, indirect, and induced economic impacts during the investment phase, we started by creating the vectors of final demand $Y^{*}$ which represent the direct impact of the project in terms of economic production. These calculations were performed by assuming that the investment phase will take 4 years (from 2016 to 2020) and that the total investment cost for this period amounts to $€ 1860 \mathrm{M}$, i.e. $€ 465 \mathrm{M}$ per annum (excluding the development phase). Based on Table 1 from the section 2 and on Junginger et al. (2004), IHS EER (2010), RIH (2011), GL BPN (2011), FEM (2011), Scottish Entreprise (2011), Sun et al. (2012) and Johnstone et al. (2013), we split the investment cost into different items of expenditure as shown in the first column of Table 2 . Then, keeping in mind that the main construction activities will be conducted in the Brittany and Normandy regions, we determined which industries would be affected (according to the

13. The number of employees by region and industry is given in the 2011 population census (INSEE, 2011).

14. During a discussion about our paper on 4 May 2016, Raphaël Dufeu from Ailes Marines SAS, the company that won the call for tender for the Saint-Brieuc project, explained that some uncertainties remain with regard to the construction process and the associated choice of suppliers due to the fragmented supply chain and the embryonic nature of the offshore wind industry in France. Therefore, assumptions that we consider in subsection 3.3 .2 with regard to cost allocation during the investment phase are reasonable. 
CPA (2008) nomenclature) as well as their relative constributions to the total investment cost (in \% and in $\mathrm{M} €$ ) which is allocated to each item of expenditure with respect to the industries involved as presented in the last four columns of Table 2 .

To convert these expenditures into a vector of final demand, we should first estimate what proportion of them will be allocated to Brittany. As indicated in ESA (2010), all transactions of single-region institutional units are allocated to the region in which such units have their predominant economic interest. The production activity usually takes place where the units are located. However, in some cases, the place of production activity can be different from the place where the unit is located, e.g. construction sector. The production value is therefore recorded in the region where the production activity takes place (and not in the place where the institutional unit is located) if the activity requires significant labour input for at least one year. Given this rule, we explain below the conversion of the cost/investment expenditures into a vector of final demand.

The first item of investment expenditures, i.e. wind turbine construction, assembly and installation, includes several different stages of production. Mainly, two stages should be distinguished: construction, and assembly and installation. Because we have no information on the breakdown of the cost between these two stages, we assumed that $50 \%$ goes to the construction stage i.e. $€ 118 \mathrm{M}$, and $50 \%$ to assembly and installation, i.e. $€ 118$ M. The construction stage includes the production of the different wind turbine components, e.g. the blade, mast and generator. According to AREVA (2012), this production is carried out by companies that are mainly located outside of Brittany, in particular in the city of Le Havre which is located in Normandy. Therefore, no expenditures can be associated with Brittany for this stage. For the assembly and installation stages, assembly will also be carried out outside of Brittany in the port of Le Havre close to where the wind turbine components will be constructed. However, for supervising the installation, we assumed that a local office will be set up in Brittany to supervise the works. We therefore considered that half the expenditures assumed to be equally divided between assembly and installation will go to the Brittany region, i.e. €59 M. In sum, we estimated that of the $€ 235 \mathrm{M}$ invested each year for wind turbine construction, assembly and installation (the first item of expenditures in Table 2), nearly $€ 60 \mathrm{M}$ will go to Brittany.

With regard to the second item of investment expenditures, i.e. foundation construction and installation, we assumed that a local office will be set up in Brittany to supervise the works. Therefore, all the expenditures induced by these activities, belonging to the construction industry classification, will be assigned to the Brittany region.

The third item of investment expenditures, i.e. marine network construction and installation, includes two stages: the construction and the installation of the marine network. We assumed that each one will involve $50 \%$ of investment expenditures, i.e. €25 M. Because BPN 2011, 2012) argue that numerous local companies in Brittany have the skills to produce electrical cable, we assumed that $50 \%$ of investment expenditures devoted to the construction stage of the marine network will benefit Brittany, in particular the electrical equipment industry, i.e. $€ 12.5 \mathrm{M}$. As for the installation phase, we assumed that some local office will be set up in Brittany to supervise the works. Thus, all investment 
367 expenditures devoted to the installation will benefit the region.

368 Finally, we assumed that all investment expenditures under the fourth item, i.e. con369 nection: cable and shore-based position, will benefit Brittany. In fact, we can safely assume 370 that at least one local site office will be set up in Brittany to coordinate the operations 371 inherent to cable and shore-based facilities.

372 Table 3 summarizes our assumptions and input data. It gives the annual investment 373 expenditures assigned to Brittany and provides the various items of the final demand vec374 tor that will be used to determine the economic impacts of the investment phase of the 375 Saint-Brieuc offshore wind project for the region of Brittany. 
Table 2 - Assumptions on investment cost allocation to items and industries according to the French aggregated nomenclature (NA-64) during the investment phase (2016-2020)

\begin{tabular}{|c|c|c|c|c|}
\hline \multirow[t]{2}{*}{ Item of expenditure } & \multirow[t]{2}{*}{ Affected industries } & \multirow{2}{*}{$\begin{array}{l}\text { Share in total cost } \\
(\%)\end{array}$} & \multicolumn{2}{|c|}{ Share in total cost $(\mathrm{M} €)$} \\
\hline & & & Total $(\mathrm{M} €)$ & $\begin{array}{l}\text { Annual } \\
(\mathrm{M} €)\end{array}$ \\
\hline Wind turbine: construction, assembly and installation & F: construction and construction works & 47 & $940^{a}$ & $235 \square$ \\
\hline Foundation: construction and installation & F: construction and construction works & 23 & $460 \bar{D}$ & $115 \square$ \\
\hline Marine network: construction and installation & $\begin{array}{l}\text { F: construction and construction works } \\
\text { C27: electrical equipment }\end{array}$ & 10 & $200 \stackrel{\bar{c}}{ }$ & $50^{\mathrm{C}}$ \\
\hline Connection: cable and shore-based facilities & F: construction and construction works & 13 & $260^{d}$ &  \\
\hline Farm development & - & 7 & $140 \bar{e}$ & $47^{\square}$ \\
\hline Total & - & 100 & 2000 & 512 \\
\hline
\end{tabular}

a. $€ 940 \mathrm{M}=€ 2 \mathrm{~B} \times 47 \%$, where $€ 2 \mathrm{~B}$ represents total CAPEX of the project and $47 \%$ the share of expenditures devoted to wind turbine

construction in the total cost. $€ 235 \mathrm{M}=\frac{€ 940 M}{4}$.

b. $€ 460 \mathrm{M}=€ 2 \mathrm{~B} \times 23 \% . € 115 \mathrm{M}=\frac{€ 460 M}{4}$.

c. $€ 200 \mathrm{M}=€ 2 \mathrm{~B} \times 10 \%$. $€ 50 \mathrm{M}=\frac{€_{200 M}}{4}$.

d. $€ 260 \mathrm{M}=€ 2 \mathrm{~B} \times 13 \%$. $€ 65 \mathrm{M}=\frac{€_{260 M}^{4}}{4}$.

e. $€ 140 \mathrm{M}=€ 2 \mathrm{~B} \times 7 \%$. $€ 47 \mathrm{M}=\frac{€_{47 M}}{4}$.

Table 3 - Assumptions on investment costs allocated to Brittany with regard to items of expenditure and affected industries during the investment phase (2016-2020)

\begin{tabular}{|c|c|c|c|c|}
\hline \multirow[t]{2}{*}{ Item of expenditure } & \multicolumn{2}{|c|}{ Affected industries } & \multirow{2}{*}{$\begin{array}{l}\text { Total cost } \\
(\mathrm{M} €)\end{array}$} & \multirow[t]{2}{*}{$\begin{array}{l}\text { Share of investment cos } \\
\text { going to Brittany }\end{array}$} \\
\hline & Construction industry & Electrical equipment industry & & \\
\hline Wind turbine: construction, assembly and installation & 60 & 0 & 60 & \\
\hline Foundation: construction and installation & 115 & 0 & 115 & \\
\hline Marine network: construction and installation & 25 & 13 & 38 & \\
\hline Connection: cable and onshore substation & 65 & 0 & 65 & \\
\hline Total $(\mathrm{M} €)$ & 253 & 25 & 278 & \\
\hline Share of investment cost going to Brittany & & & & $60 \%=\frac{€_{278 M}}{€_{465 M}}$ \\
\hline
\end{tabular}




\subsubsection{Impact calculation during the O\&M phase}

Economic impacts during the O\&M phase arise from the production and maintenance activities of the Saint-Brieuc offshore wind farm.

We used the output approach to estimate the direct impact of the project in terms of economic production (European Commission et al. (2009)). We multiplied the expected physical production by the expected unitary price. According to Iberdrola and Eole-Res (2012a, 2012b), AREVA (2012) and CRE (2012), the expected production is $1750 \mathrm{GWh}$ per annum and the unitary net price $€ 66,500$ per GWh $(\mathrm{CRE}, 2012)$. The value of economic production is therefore estimated at $€ 116 \mathrm{M}$ per annum. According to Lehr et al. (2008), the rate of added value is equal to $50 \%$, thus, the added value is about $€ 58 \mathrm{M}$. With regard to employment, based on Oxford Economics (2010), Colbert-Busch et al. (2012), Zammit and Miles (2013) and Sercy et al. (2014), we used a weighted average value of estimations of the expected number of jobs calculated for offshore wind farms during the O\&M phase ${ }^{15}$ equal to 0.4 FTE jobs per MW ${ }^{16}$. Applying this value implies that the Saint-Brieuc offshore wind farm totaling 500 MW will have a staff of 200 employees.

To estimate the indirect and induced impacts, we assumed that the production process -different inputs representing intermediate consumption as well as primary inputs such as labour and capital-of offshore wind is quite similar to the production process of onshore wind because current offshore wind technologies are based on onshore wind technology (Sun et al., 2012). Therefore, we referred to the Lehr et al. (2008) study, which estimated the different inputs/intermediate consumption required to produce one monetary unit of the electricity produced by wind energy farms (see Table 4) to estimate the indirect and the induced impacts inherent to the O\&M phase. More specifically, we calculated indirect and induced impacts using the matrix of regional technical coefficients from respectively the open and the closed Leontief models (1986) (see Appendix D. We used equations 4 to 9 and equations 10 to 15 to respectively calculate indirect and induced impacts.

\section{Results and some policy implications}

In subsection 4.1, we summarize results and carry out a comparative analysis. We note that according to the available information, we successfully carried out a comparative analysis on employment impacts only. In subsection 4.2, we give some policy implications.

\subsection{Presentation of results and comparative analysis}

Table $5 \mathrm{a}$ summarizes results. It details annual direct, indirect, and induced impacts in $\mathrm{M} €$ and per MW for each phase of the project. Our results show that the highest relative impacts occur during the investment phase. In particular, during this phase (from 2016 to 2020), economic production is expected to total $€ 442 \mathrm{M}$ and gross added value $€ 191 \mathrm{M}$, or on a per-annum basis $€ 0.88 \mathrm{M} /$ year/MW and $€ 0.38 \mathrm{M} /$ year/MW. They also

15. After eliminating the highest value calculated by Zammit and Miles (2013).

16. Details about estimations of Oxford Economics (2010), Colbert-Busch et al. (2012), Zammit and Miles (2013) and Sercy et al. (2014) are presented in Tables 6 and E.2 (Appendix E). 
Table 4 - Values of inputs required for the production of one monetary unit of power from the Saint-Brieuc offshore wind farm (Duong et al. (2009), Lehr et al. (2008))

\begin{tabular}{|c|c|c|}
\hline $\begin{array}{l}\text { Nomenclature } \\
\text { (CPA 2008) }\end{array}$ & Title & Value $(€)$ \\
\hline $\mathrm{C} 22-\mathrm{C} 23$ & $\begin{array}{l}\text { Rubber and plastic products and other products made of non- } \\
\text { metallic elements }\end{array}$ & 0.015 \\
\hline $\mathrm{C} 25$ & $\begin{array}{l}\text { Manufactured metal products, except machinery and equip- } \\
\text { ment }\end{array}$ & 0.095 \\
\hline $\mathrm{C} 27$ & Electrical equipment & 0.125 \\
\hline $\mathrm{C} 28$ & Machinery and equipment n.e.c. & 0.090 \\
\hline C29-C30 & Transportation equipment & 0.050 \\
\hline $\mathrm{F}$ & Construction and construction works & 0.030 \\
\hline G & Wholesale and retail trade services & 0.055 \\
\hline $\mathrm{H}$ & Transportation and storage services & 0.010 \\
\hline $\mathrm{K}$ & Financial and insurance services & 0.015 \\
\hline \multirow[t]{7}{*}{ LZ } & Real estate services & 0.015 \\
\hline & Total intermediate consumption & 0.500 \\
\hline & Employee compensation & 0.120 \\
\hline & Other net taxes on production & 0.025 \\
\hline & Operating surplus, net & 0.355 \\
\hline & Added value & 0.500 \\
\hline & Production & 1 \\
\hline
\end{tabular}

412 show that the investment phase creates 3016 FTE jobs which is the equivalent of 6.03

413 FTE jobs/year/MW. During the O\&M phase lasting from 2020 to 2040, annual economic 414 production and gross added value are expected to respectively reach $€ 163 \mathrm{M}$ or $€ 0.32$ $415 \mathrm{M} /$ year/MW and $€ 79 \mathrm{M}$ or $€ 0.15 \mathrm{M} /$ year/MW. For employment, $511 \mathrm{FTE}$ jobs, thus, $4161.02 \mathrm{FTE}$ jobs year/MW are expected annually. These results indicate that the project 417 will increase the GDP of Brittany by $0.22 \%$ and $0.09 \%$ during the investment and O\&M phases, respectively 17 .

Table 5a - Summary of annual economic impacts for Brittany

\begin{tabular}{|c|c|c|c|}
\hline Type of impact & Economic production $(\mathrm{M} €)$ & Added value $(\mathrm{M} €)$ & Jobs (FTE) \\
\hline & \multicolumn{3}{|c|}{ The investment phase (2016-2020) } \\
\hline Direct impacts & 278 & 111 & 1919 \\
\hline Indirect impacts & 68 & 30 & 460 \\
\hline Induced impacts & 96 & 50 & 637 \\
\hline Total & 442 & 191 & 3016 \\
\hline Total per MW & $0.88^{a}$ & $0.38^{a}$ & $6.03^{a}$ \\
\hline & \multicolumn{3}{|c|}{ The O\&M phase $(2020-2040)$} \\
\hline Direct impacts & 116 & 58 & 200 \\
\hline Indirect impacts & 26 & 10 & 153 \\
\hline Induced impacts & 21 & 11 & 158 \\
\hline Total & 163 & 79 & 511 \\
\hline Total per MW & $0.32^{b}$ & $0.15^{b}$ & $1.02^{b}$ \\
\hline
\end{tabular}

a. $0.88=\frac{442}{500}, 0.38=\frac{191}{500}, 6.03=\frac{3016}{500}$

b. $0.32=\frac{163}{500}, 0.15=\frac{79}{500}, 1.02=\frac{511}{500}$

419 Based on two literature reviews respectively dealing with the quantification of the 420 economic impacts of the Saint-Brieuc offshore wind project (Table E.1 from Appendix

17. Calculations were done with respect to the 2013 GDP level which is equal to $€ 86,934 \mathrm{M}$. 
Table 5b - Summary of annual economic impacts for France

\begin{tabular}{|c|c|c|c|}
\hline Type of impacts & Economic production $(\mathrm{M} €)$ & Added value $(\mathrm{M} €)$ & Jobs (FTE) \\
\hline & \multicolumn{3}{|c|}{ The investment phase $(2016-2020)$} \\
\hline Direct impacts & 465 & 189 & 3277 \\
\hline Indirect impacts & 399 & 181 & 2874 \\
\hline Induced impacts & 487 & 135 & 3373 \\
\hline Total & 1351 & 505 & 9524 \\
\hline \multirow[t]{2}{*}{ Total per MW } & $2.70^{a}$ & $1.01 \sqrt{a}$ & $19.04 \sqrt{a}$ \\
\hline & \multicolumn{3}{|c|}{ The O\&M phase (2020-2040) } \\
\hline Direct impacts & 116 & 58 & 200 \\
\hline Indirect impacts & 67 & 27 & 357 \\
\hline Induced impacts & 57 & 34 & 449 \\
\hline Total & 239 & 119 & 1006 \\
\hline Total per MW & $0.47^{b}$ & $0.23 b$ & $2.01 \mathrm{~b}$ \\
\hline
\end{tabular}

a. $2.70=\frac{1351}{500}, 1.01=\frac{505}{500}, 19.04=\frac{9524}{500}$

b. $0.47=\frac{239}{500}, 0.23=\frac{119}{500}, 2.01=\frac{1006}{500}$

Table $5 \mathrm{c}-$ Contribution of Brittany to total economic impacts

\begin{tabular}{|c|c|c|c|}
\hline Type of impacts & Economic production & Added value & Jobs \\
\hline & \multicolumn{3}{|c|}{ The investment phase (2016-2020) } \\
\hline Direct impacts & $60 \%$ & $59 \%$ & $59 \%$ \\
\hline Indirect impacts & $17 \%$ & $17 \%$ & $16 \%$ \\
\hline Induced impacts & $20 \%$ & $37 \%$ & $19 \%$ \\
\hline Total & $33 \%$ & $38 \%$ & $32 \%$ \\
\hline & \multicolumn{3}{|c|}{ The O\&M phase (2020-2040) } \\
\hline Direct impacts & $100 \%$ & $100 \%$ & $100 \%$ \\
\hline Indirect impacts & $39 \%$ & $37 \%$ & $43 \%$ \\
\hline Induced impacts & $37 \%$ & $32 \%$ & $35 \%$ \\
\hline Total & $68 \%$ & $66 \%$ & $51 \%$ \\
\hline
\end{tabular}

$421 \mathrm{E}^{18}$ and overseas offshore wind projects (Table E.2 from Appendix E), Table 6 presents a comparative analysis on the employment generated by the Saint-Brieuc offshore wind farm 19. Part I of this table which gives the results of studies assessing the economic impacts of the Saint-Brieuc offshore wind farm shows that our expected levels of employment in Brittany during the investment and O\&M phases, considered separately, are relatively optimistic. In particular, our results foresee 1919 direct FTE jobs in Brittany during the investment phase. Similarly, Nass\&Wind (2011) states that between 1500 to 2000 direct

18. None of estimations quoted in Table E.1 from Appendix E and Part I of Table 6 have been published in the academic literature. They were collected from various internet sources, i.e. reports, press conference documents, the local press, which usually provide no details on the methodology used.

19. Although it is widely accepted that results from different assessment exercises can vary and sometimes conflict, we wish to emphasize that our comparative analysis should be considered with caution in particular, due to discrepancies with regard to how jobs are defined. For example, Simas and Pacca (2014) argue that "manufacturing of key components, power plant construction and OESM are considered direct jobs. However, some studies include planning and project management, research and development, energy companies, utilities, banks, and other services". They add that "the definition of indirect jobs is even vaguer. While some authors estimate the indirect effects of materials and services consumed on the upstream supply chain, other studies consider consultancies and several minor components not directly related to the sector. There are also studies which include induced jobs in the final quantification. Usually job losses in other energy industries due to high investments costs of renewable energy technologies is not accounted for. The treatment of the differences between temporary and permanent jobs is also an issue that is often not addressed." 
428 FTE jobs will be generated whatever the region. During the O\&M phase, Nass\&Wind (2011) and Oxford Economics (2010) respectively estimated the total expected number of direct FTE jobs for all regions/geographical areas at 60 and $110^{20}$. However, our results suggest that 200 FTE jobs will be created in Brittany.

Considering the aggregated impact of the investment and O\&M phases on employment, the comparative analysis shows that the number of expected jobs in Brittany estimated by Ailes Marines SAS (2014c) is lower than our estimates. In contrast to their assertion that 1000 direct FTE jobs will be created, our results suggest that there will be 2119 direct FTE jobs. Similarly, when compared to estimations of BPN (2011), quoted in CCICA (2011), our results show that a large part of employment generated will occur in Brittany: more precisely, of the 2500 direct FTE jobs, 2119 will be located in Brittany. Conversely, compared with results of EWEA (2009a) showing that 5500 direct and indirect jobs can be expected of the Saint-Brieuc project, our results indicate that only 2732 direct and indirect jobs can be expected.

When comparing our results with those of overseas offshore wind farms having an equivalent size to the Saint-Brieuc farm, i.e. $500 \mathrm{MW}$, as reported in Part II of Table $6{ }^{21}$. we found high variability. For example, US DE (2013) corroborate our results. They state that for a farm of $500 \mathrm{MW}, 4.99 \mathrm{FTE}$ jobs per MW and 1.66 FTE jobs per MW (per annum) are expected during the investment and O\&M phases, respectively, which is comparable to our results, i.e. 6.03 FTE jobs per MW and 1.02 FTE jobs per MW (per annum) during the same respective phases. Nevertheless, Oxford Economics (2010) and ColbertBusch et al. (2012) indicate that our results overestimate employment impacts during the investment and the O\&M phases. For example, according to Colbert-Busch et al. (2012), $500 \mathrm{MW}$ of installed offshore wind capacity can engender 3.62 FTE jobs/year/MW during the investment phase and 0.67 during the O\&M phase. Conversely, estimations from Sercy et al. (2014) and Zammit and Miles (2013) reveal that our results comparatively underestimate impacts during the investment. For instance, although our results predict 6.03 FTE jobs per MW, Zammit and Miles (2013) states that 19 FTE jobs per MW can be created. As for total employment impact, results of Flynn and Carey (2007) appear to suggest that we overestimate the expected total number of jobs, i.e. 7.05 per MW (per annum) compared with 3.92 jobs per MW.

Since at this stage of the analysis, we only assessed regional impacts of the project, we extended our study by evaluating national impacts (see below) to quantify the share of wealth and employment captured by the Brittany region. Therefore, we performed the same I-O analysis on the French national I-O table. Similar to the regional assessment, the two phases of the project were treated separately, i.e. investment and O\&M. Again, for the investment phase -in analogy to the regional impacts assessment (see Table 3)-, we assumed that $60 \%$ of cost expenditures will be located in France (nationwide). The results of this exercise are given in Tables $5 \mathrm{~b}$ and $5 \mathrm{c}$.

20. Average value.

21. As shown in Table E.2 from Appendix E estimations quoted in Part II of Table 6 were generated from modelling exercises based on well-founded theoretical approaches contrary to estimations presented in Part I of the same table (see also footnote 18. 
They show that at the national level, during the investment phase, the Saint-Brieuc project will generate an added value amounting to $€ 1.01 \mathrm{M} /$ year/MW (compared with $€ 0.38 \mathrm{M}$ in Brittany) and 19.04 FTE jobs/year/MW (compared with $6.03 \mathrm{FTE}$ jobs in Brittany). Using these results to calculate the share that Brittany carries in terms of total impacts (see Table 3) shows that the Brittany region captures 38\% of wealth and $32 \%$ of jobs created by the Saint-Brieuc project. These low values can be explained, firstly, by relatively small low investment expenditures allocated to the Brittany region, i.e. $60 \%$ according to our assumption ${ }^{22}$ and, secondly (to a lesser extent), the loss of wealth induced by inter-regional imports.

For the O\&M phase, the Saint-Brieuc project is expected generate an added value equal to $€ 0.23 \mathrm{M} /$ year $/ \mathrm{MW}$ (compared with $€ 0.15 \mathrm{M}$ in Brittany). Moreover, it will sustain 2.01 FTE jobs/year/MW (compared with 1.02 FTE jobs in Brittany). Therefore, the Brittany region is predicted to capture $66 \%$ of the wealth and $51 \%$ of the jobs created by the project. Thus, contrary to the investment phase, Brittany can benefit quite well from the economic impacts induced by the O\&M phase 23 .

In sum, depending on the proportion of regional investment that will be decided by stakeholders and on which we have made assumptions to feed our I-O model, i.e. 60\%, Brittany can benefit from positive wealth and employment impacts. The magnitude of these impacts is nevertheless small. In particular, the project is expected to increase the regional GDP by $0.22 \%$ and $0.09 \%$ during the investment and O\&M phases, respectively, which corresponds to $38 \%$ and $66 \%$ of national economic impacts. As for employment impacts, $32 \%$ and $51 \%$ part will be captured by Brittany during the same phases.

22. We note that according to our I-O model, the economic multipliers are strong. For instance, an expense of $€ 1$ generates a production value of $€ 2.90$. This means that the investment expenditures have strong ripple effects. Similarly, for the employment multiplier, an expense of $€ 1$ generates 20.48 FTE jobs. Therefore, the main reason for the weak economic impacts of the project in Brittany compared with the national level is the low relative proportion of regional investment expenditures.

23. The loss of wealth for Brittany during the O\&M phase is solely attributed to inter-regional imports. In fact, during this phase, multiplier effects are low. For instance, an expense of $€ 1$ generates a production value of $€ 2.06$. This means that the O\&M expenditures have a relatively weak ripple effects. Similarly, for the employment multiplier, an expense of $€ 1$ generates only 8.67 FTE jobs. 
Table 6 - Comparative analysis on the employment impact of the Saint-Brieuc offshore wind farm [based on Tables E.1 and E.2]

\begin{tabular}{|c|c|c|c|c|}
\hline \multirow[t]{2}{*}{ Reference } & \multirow[t]{2}{*}{ Phase } & \multicolumn{2}{|c|}{ Results } & \multirow[t]{2}{*}{ Comments on the jobs considered in the reference } \\
\hline & & Reference & Our model & \\
\hline \multirow{2}{*}{\multicolumn{5}{|c|}{$\begin{array}{c}\text { Part I } \\
\text { Comparison of our results (see Table } 5 \mathrm{a} \text {, with those from other studies on the employment impact of the Saint-Brieuc offshore wind farm (see Table E.1. }\end{array}$}} \\
\hline & & & & \\
\hline \begin{tabular}{|l|} 
Ailes $\quad$ Marines \\
SAS $(2014 \mathrm{c})$
\end{tabular} & $\begin{array}{l}\text { Manufacturing, installation, and } \\
\text { O\&M }\end{array}$ & 1000 jobs & 2119 jobs & $2119=1919+200$. Only direct jobs were considered. \\
\hline \multirow[t]{2}{*}{ Nass\&Wind } & Manufacturing and installation & {$[1500-2000]$ jobs 25} & 1919 jobs & Indirect and induced jobs do not appear to be considered. \\
\hline & O\&M & 60 jobs 25 & 200 jobs & Only direct jobs were considered. \\
\hline \begin{tabular}{|l|} 
Oxford $\quad$ Eco- \\
nomics $\sqrt{2010}[24]$
\end{tabular} & O\&M & $[95-125]$ jobs 25$]$ & 200 jobs & Only direct jobs appear to be considered. \\
\hline \multirow[t]{2}{*}{ EWEA } & Global impacts & 5500 jobs 25 & 2732 jobs & $\begin{array}{l}2732=1919+460+200+153 . \text { Induced jobs were not consid- } \\
\text { ered. }\end{array}$ \\
\hline & O\&M & 150 jobs 25 & 353 jobs & $353=200+153$. Induced jobs were not considered. \\
\hline \multirow[t]{2}{*}{$\begin{array}{l}\text { European Com- } \\
\text { mission }(2001)^{24}\end{array}$} & $\begin{array}{l}\text { Conception, development, manufac- } \\
\text { turing, installation and O\&M }\end{array}$ & $[2010-2250]$ jobs 25$]$ & 1919 jobs & Only direct jobs appear to be considered. \\
\hline & O\&M & 30 jobs 25 & 200 jobs & Only direct jobs appear to be considered. \\
\hline \multirow[t]{2}{*}{$\mathrm{BPN}[24]$} & Global impacts & 2500 jobs 25 & 1919 jobs & Only direct jobs appear to be considered. \\
\hline & O\&M & $[60-80]$ jobs 25$]$ & 200 jobs & Only direct jobs appear to be considered. \\
\hline \multicolumn{5}{|c|}{ Part II } \\
\hline \multirow[t]{2}{*}{ Sercy } & $\begin{array}{l}\text { Construction and component manu- } \\
\text { facturing }\end{array}$ & 23.97 jobs per $\mathrm{MW}$ & 6.03 jobs per MW & $23.97=\frac{959}{40}$ \\
\hline & O\&M & $\begin{array}{l}0.25 \text { jobs per MW (per an- } \\
\text { num) }\end{array}$ & $\begin{array}{l}1.02 \text { jobs per MW (per an- } \\
\text { num) }\end{array}$ & $0.25=\frac{10}{40}$ \\
\hline \multirow[t]{2}{*}{ US DE 2013) } & Construction & 4.99 jobs per $\mathrm{MW}$ & 6.03 jobs per MW & $4.99=\frac{20100}{4027}$ \\
\hline & O\&M & $\begin{array}{l}1.66 \text { jobs per MW (per an- } \\
\text { num) }\end{array}$ & $\begin{array}{l}1.02 \text { jobs per MW (per an- } \\
\text { num) }\end{array}$ & $1.66=\frac{6700}{4027}$ \\
\hline $\begin{array}{l}\text { Zammit and } \\
\text { Miles } \sqrt{2013)}\end{array}$ & Construction & [19-39] jobs per MW & 6.03 jobs per MW & - \\
\hline
\end{tabular}

24. Quoted in CCICA (2011).

25. This estimation is relative not only to Brittany but also to all geographical areas that can be affected by the project. 
Table 6 - Complete the previous page

\begin{tabular}{|c|c|c|c|c|}
\hline \multirow[t]{2}{*}{ Reference } & \multirow[t]{2}{*}{ Phase } & \multicolumn{2}{|c|}{ Results } & \multirow[t]{2}{*}{ Comments on the jobs considered in the reference } \\
\hline & & Reference & Our model & \\
\hline & $\mathrm{O} \& \mathrm{M}$ & [1.64-1.67] per MW & $\begin{array}{l}1.02 \text { jobs per MW (per an- } \\
\text { num) }\end{array}$ & - \\
\hline \multirow[t]{2}{*}{$\begin{array}{l}\text { Colbert-Busch } \\
\text { et al. }(2012 \text {, }\end{array}$} & $\begin{array}{l}\text { Component manufacturing and instal- } \\
\text { lation }\end{array}$ & $\begin{array}{l}3.62 \text { jobs per MW (per an- } \\
\text { num) }\end{array}$ & $\begin{array}{l}6.03 \text { jobs per MW (per an- } \\
\text { num) }\end{array}$ & $3.62=\frac{293+3329}{1000}$ \\
\hline & O\&M & $\begin{array}{l}0.67 \text { jobs per MW (per an- } \\
\text { num) }\end{array}$ & $\begin{array}{l}1.02 \text { jobs per MW (per an- } \\
\text { num) }\end{array}$ & $0.67=\frac{678}{1000}$ \\
\hline \begin{tabular}{|l|} 
Oxford $\quad$ Eco- \\
nomics 2010 \\
\end{tabular} & $\mathrm{O} \& \mathrm{M}$ & $\begin{array}{l}{\left[0.35\left[{ }^{26}-0.45{ }^{27}\right] \text { jobs per }\right.} \\
\text { MW }\end{array}$ & 1.02 per MW (per annum) & $0.35=\frac{7230}{25000}$ and $0.45=\frac{450}{1000}$ \\
\hline EWEA 2009a) & $\begin{array}{l}\text { Farm development, turbine and com- } \\
\text { ponent manufacturing, and installa- } \\
\text { tion. } \\
\text { O\&M }\end{array}$ & $\begin{array}{l}0.33 \text { jobs per (cumulative) } \\
\text { MW }\end{array}$ & $\begin{array}{l}1.02 \text { jobs per MW (per an- } \\
\text { num) }\end{array}$ & $\begin{array}{l}\text { Number of jobs includes both offshore and onshore wind. In- } \\
\text { duced jobs were not considered. }\end{array}$ \\
\hline $\begin{array}{l}\text { Boettcher et al. } \\
2008,\end{array}$ & O\&M & 0.34 jobs per $\mathrm{MW}$ & 1.02 jobs per MW (annual) & $0.34=\frac{6734}{20000}$ \\
\hline \multirow[t]{2}{*}{ Carbon } & $\begin{array}{l}\mathrm{R} \& \mathrm{D} \text {, engineering and design, tur- } \\
\text { bine and component manufacturing } \\
\text { and services }\end{array}$ & {$[1.10-1.41]$ jobs per MW } & 6.03 jobs per $\mathrm{MW}$ & $1.10=\frac{32000}{29000}$ and $1.41=\frac{41000}{29000}$ \\
\hline & Installation and O\&M & {$[0.27-1]$ per MW } & 1.05 per MW (per annum) & $0.27=\frac{8000}{29000}$ and $1=\frac{29000}{20000}$ \\
\hline \multirow[t]{2}{*}{ GWEC (2008) } & $\begin{array}{l}\text { Farm development, turbine and com- } \\
\text { ponent manufacturing, and installa- } \\
\text { tion }\end{array}$ & 15.1 jobs/year/ MW[28] & n.a. & $\begin{array}{l}\text { Estimation in GWEC (2008) is extracted from EWEA } 2009 \mathrm{a}) \text {. } \\
\text { Includes both offshore and onshore wind. Induced jobs were not } \\
\text { considered. }\end{array}$ \\
\hline & O\&M & $\begin{array}{l}0.33 \text { jobs per (cumulative) } \\
\text { MW }\end{array}$ & $\begin{array}{l}1.02 \text { jobs per MW (per an- } \\
\text { num) }\end{array}$ & \\
\hline $\begin{array}{l}\text { Flynn and Carey } \\
2007,\end{array}$ & $\begin{array}{l}\text { Manufacturing, installation, and } \\
\text { O\&M }\end{array}$ & 3.92 jobs per $\mathrm{MW}$ & $\begin{array}{l}7.05 \text { per } \text { MW (per an- } \\
\text { num) }\end{array}$ & $3.92=\frac{1881}{480}$ \\
\hline
\end{tabular}

26. This estimation is associated with an expected installed capacity of $20.5 \mathrm{GW}$ by 2020 .

27. This estimation is associated with an installed capacity of 1 GW by 2010 .

28. This means 15.1 jobs per additional installed MW in one year.

29. $7.05=6.03+1.02$ where 6.03 represents the number of jobs per MW (per annum) during the investment phase and 1.02 the number of jobs per MW (per annum) during O\&M. 


\subsection{Policy implications}

As shown by our results, although the local project off Saint-Brieuc is expected to induce positive employment impacts, these impacts are nevertheless small. However, with the recent ambition of France to establish a strong national offshore wind industry, more significant impacts may ensue. In France, one criterion for the evaluation of applications in response to calls for tender for offshore wind is the "industrial and social quality of the project", which accounts for $40 \%$ of the total score and aims to foster the industrial development of offshore wind in France by encouraging nationwide organization of the value chain, nationwide creation of economic activity, and nationwide development of experience curve effects (CRE, 2011). In this context, to construct turbines, Alstom 30 for instance, is expected to set up two factories in Saint Nazaire (Pays-de-la-Loire region) for the construction of generators and nacelles, two factories in Cherbourg (Normandy) for the construction of blades and masts, and an engineering centre in the Pays-de-la-Loire region devoted to support the creation of an independent offshore wind industry. Also, areas in the ports of Le Havre (Normandy), Cherbourg, Brest (Brittany) and Saint-Nazaire are dedicated to the pre-assembly and installation phases (Ailes Marines SAS, 2012). Similarly, Ailes Marines SAS 31 has defined a development program that aims at establishing a sustainable and independent French offshore wind industry with both local and export development opportunities. Under this programme, human resources and local companies (mainly in Brittany) have been identified to be involved in different roles along the supply chain (MERiFIC (2013a), Ailes Marines SAS (2013a), BPN (2012), CESER (2012)).

When focusing on human resources and employment impacts, a crucial step is to start setting up measures to develop a skilled workforce. Given the embryonic nature of the offshore wind industry in France, its fragmented supply chain and the uncertainty with regard to its future development prospects, a shortage of skilled workers in some roles, e.g. offshore security and maintenance technicians, can be expected (Gautier, 2010). In the short term, the supply of skilled workers is likely to come from other sectors including the onshore wind, offshore oil and gas, automotive and aerospace sectors, although there are challenges in attracting experienced workers. Alternatively, the workforce can be sourced internationally within the framework of overseas collaborations that may promote knowledge transfers. In the long term, after identifying needs when possible, it is important to define a long-term strategy for workforce training and planning. The offer of training courses should operate on both levels of education and training, both initial and continuing. It is also important to ensure that instructors are certified through professional training courses (formation professionnelle) because this consolidates the promotion of jobs specific to offshore wind 32 Interestingly, by developing a skilled workforce, France could export its

30. Alstom is a member of Éolien Maritime France, the consortium that bid on and won the tender for the Fécamp (Seine-Maritime, 500 MW), Courseulles-sur-mer (Calvados, 500 MW), and Saint-Nazaire (Loire-Atlantique, $750 \mathrm{MW}$ ) offshore wind farms.

31. Ailes Marines SAS won the tender for the Saint-Brieuc offshore wind farm (Côtes d'Armor, 500 MW).

32. The main institutions delivering training courses related to offshore wind in particular and to marine renewable energies in general in France are L'École Centrale of Nantes (http://www.ec-nantes.fr/), L'ENSTA Bretagne of Brest (http://www.ensta-bretagne.fr/), L'École Navale (http://www.ecole- 
know-how and thereby enhance local employment impacts. For example, the five Haliade 150-6 MW offshore wind turbines of the American Block Island Wind farm, currently in operation, were manufactured by the French Alstom Group at its factory in Saint-Nazaire.

Obviously, measures aiming at developing a skilled workforce should be associated with other measures focusing on ensuring electricity price accessibility for consumers, stabilizing the regulatory and legal frameworks for wind power and enhancing the social acceptability of wind turbines. In the preliminary stage of offshore wind development, reducing investment costs and thus electricity prices, is a key lever to ensuring the large-scale deployment of offshore wind. In the long run, cost reduction can be expected due to the accumulation of experience and economies of scale. IRENA (2016) argues that costs have fallen more than $30 \%$ in the 15 years since the first wind farm opened. Wiser et al. (2016) also expects, although uncertainties persist, cost reductions of $24-30 \%$ by 2030 and $35-41 \%$ by 2050 . Nevertheless, as stated by Blanco (2009), Snyder and Kaiser (2009), and Musial and Ram (2010), in the short and medium terms, public financial support mechanisms are crucial to cope with high costs. In this context, IRENA (2016) argues that cost reductions have been aided by government financial support to address the security of electricity supply and the decarbonization of electricity production.

a Currently in France, investment costs are borne by the private sector Ailes Marines SAS, 2013a). Government financial support to offshore wind is indirect and goes through feed-in tariffs. For an operation period of 20 years, it was set at $€ 130 /$ MWh for the first 10 years and between $€ 30$ to $130 /$ MWh for the last 10 years depending on the geographical location of the farm. The CSPE "Contribution au Service Public de l'Électricité" finances feed-in tariffs because it aims to have local and regional governments bear the additional financial burden engendered by the production of electricity from renewable sources in general and offshore wind in particular. According to CRE (2012), the additional financial costs that will be generated by the four scheduled offshore wind farms from the first French call for tender amount to $€ 1.1 \mathrm{~B}$ per year starting from 202033

\section{Conclusion}

While opponents to the large-scale deployment of offshore wind usually point out its high cost and lack of competitiveness, its advocates argue that expected economic benefits can be high. This paper presents a case study to assess local economic impacts of the 500 MW offshore wind farm off Saint-Brieuc in Brittany, in particular employment impacts. We used a regional I-O model that we implemented with the few available data on the project in an informative way to paint a robust picture of deployment prospects of offshore wind in France and its expected impacts.

Results show that depending on the rate of regional investment with respect to the supply chain roles, the project weakly, but nevertheless positively, impacts Brittany's economy. It is expected to increase the GDP of Brittany by $0.22 \%$ and $0.09 \%$ during the investment and O\&M phases, respectively. More specifically, during the investment phase $€ 0.88$

navale.fr/), maritime secondary schools, and maritime vocational schools (Gautier. 2010).

33. This corresponds to an additional annual cost of $€ 160 / \mathrm{MWh}$. 
$564 \mathrm{M} /$ year/MW of economic production, $€ 0.38 \mathrm{M} /$ year/MW of gross added value, and 6.03

565 FTE jobs/year/MW are expected. During the O\&M phase, $€ 0.32 \mathrm{M} /$ year/MW of eco566 nomic production, $€ 0.15 \mathrm{M} /$ year/MW of gross added value, and 1.02 FTE jobs/year/MW

567 are also expected. Compared to the national impacts of the project, these results imply 568 that $38 \%$ and $66 \%$ of wealth creation will be captured by the Brittany region during the 569 investment and O\&M phases, respectively. They also imply that $32 \%$ and $51 \%$ of employ570 ment impacts will be benefit Brittany during the same phases.

571 These results shed light on the potential role that offshore wind investments can play in 572 the long run in stimulating economic development mainly at the local scale. In particular, 573 through the development of new economic sectors, job creation, and consumer spending, 574 such investments are expected to enhance regional economies. Therefore, in a context of 575 economic deceleration in France associated with recurrent and alarming debates over re576 source depletion and climate change issues, accelerating the development of offshore wind 577 represents an opportunity. Nevertheless, in France, there is currently a profound need to 578 revise the economic, technological, legal, regulatory and social frameworks within which 579 the offshore wind industry is currently emerging to establish the conditions for its sustain580 able development. Despite the scheduled farm construction after the three calls for tender 581 in July 2011, March 2013, and December 2016, the offshore wind industry is still in its 582 early stages because the cost of offshore electricity is currently very high, the supply chain 583 is fragmented, the regulatory context is uncertain, the legal framework is undefined, and 584 the social acceptability is shaky. Short-run and long-run measures targeting to support 585 both the demand and the supply sides are necessary. We particularly advocate technology 586 incentives, e.g. government $\mathrm{R} \& \mathrm{D}$, subsidies, tax credit, which all promote early knowl587 edge transfer and overcome barriers to market entry, and market pull, i.e. feed-in tariffs, 588 Renewables Obligations (RO), taxes, measures devoted to enhancing the deployment of 589 wind technology by creating demand and developing markets. Successful experiences in 590 the UK or Denmark show the effectiveness of the combination of both of these two types 591 of measures. Conversely, they also highlight that France is lagging behind in mobiliz ing 592 its human, technological and geographical resources to develop its offshore wind industry. 593 Regional collaborations and international cooperation can surely accelerate the process 594 and offer wider benefits. 


\section{A Overview of the global offshore wind capacity 34}

Table A.1 - Global cumulative offshore wind capacity in 2015 and 2016

\begin{tabular}{lcc}
\hline & \multicolumn{2}{c}{ Installed capacity (MW) } \\
\cline { 2 - 3 } Country & 2015 & 2016 \\
\hline UK & 5100 & 5156 \\
Germany & 3295 & 4108 \\
PR China & 1035 & 1627 \\
Denmark & 1271 & 1271 \\
Netherlands & 427 & 1118 \\
Belgium & 712 & 712 \\
Sweden & 202 & 202 \\
Japan & 53 & 60 \\
S. Korea & 5 & 35 \\
Finland & 32 & 32 \\
US & 0.02 & 30 \\
Ireland & 25 & 25 \\
Spain & 5 & 5 \\
Norway & 2 & 2 \\
Portugal & 2 & 0 \\
\hline Total & 12,167 & 14,384 \\
\hline
\end{tabular}

Table A.2 - The 25 largest operational offshore wind farms in the world in 2016

\begin{tabular}{|c|c|c|c|c|}
\hline Farm & $\begin{array}{l}\text { Capacity } \\
\text { (MW) }\end{array}$ & Country & $\begin{array}{l}\text { Number of } \\
\text { turbines }\end{array}$ & Commissioning date \\
\hline London Array & 630 & UK & 175 & 2012 \\
\hline Gwynt y Môr & 576 & UK & 160 & 2015 \\
\hline Greater Gabbard & 504 & UK & 140 & 2012 \\
\hline Anholt & 400 & Denmark & 111 & 2013 \\
\hline BARD Offshore 1 & 400 & Germany & 80 & 2013 \\
\hline Global Tech I & 400 & Germany & 80 & 2015 \\
\hline West of Duddon Sands & 389 & UK & 108 & 2014 \\
\hline Walney (phases 1\&2) & 367.2 & UK & 102 & $\begin{array}{l}2011 \text { (phase 1) } \\
2012 \text { (phase 2) }\end{array}$ \\
\hline Thorntonbank (phases 1-3) & 325 & Belgium & 54 & $\begin{array}{l}2009 \text { (phase } 1) \\
2012 \text { (phase } 2) \\
2013 \text { (phase } 3)\end{array}$ \\
\hline Sheringham Shoal & 315 & UK & 88 & 2012 \\
\hline Borkum Riffgrund 1 & 312 & Germany & 78 & 2015 \\
\hline Thanet & 300 & UK & 100 & 2010 \\
\hline Nordsee Ost & 295 & Germany & 48 & 2015 \\
\hline Amrumbank West & 288 & Germany & 80 & 2015 \\
\hline Butendiek & 288 & Germany & 80 & 2015 \\
\hline DanTysk & 288 & Germany & 80 & 2015 \\
\hline EnBW Baltic 2 & 288 & Germany & 80 & 2015 \\
\hline Meerwind Süd/Ost & 288 & Germany & 80 & 2015 \\
\hline Lincs & 270 & UK & 75 & 2013 \\
\hline Humber Gateway & 219 & UK & 73 & 2015 \\
\hline Northwind & 216 & Belgium & 72 & 2014 \\
\hline Westermost Rough & 210 & UK & 35 & 2015 \\
\hline Homs Rev II & 209.3 & Denmark & 91 & 2009 \\
\hline RØdsand II & 207 & Denmark & 91 & 2010 \\
\hline Chenjiagang (Jiangsu) Xiangshui & 201 & China & 134 & 2010 \\
\hline
\end{tabular}

34. Information contained in Tables A.1 and A.2 was extracted from www.gwec.com [Accessed 31 March 2017]. 


\section{B Supplementary information on offshore wind in France}

\section{B.1 General}

598 In July 2011, the first call for tender was launched by the French government for in599 stalling $3 \mathrm{GW}$ of offshore wind power in five areas in north-western France: Dieppe-Le 600 Tréport (Seine-Maritime département, 750 MW), Fécamp (Seine-Maritime département, $601500 \mathrm{MW}$ ), Courseulles-sur-mer (Calvados département, 500 MW), Saint-Nazaire (Loire602 Atlantique département, $750 \mathrm{MW}$ ) and Saint-Brieuc (Côtes d'Armor département, 500 $603 \mathrm{MW})$. Only the Dieppe-Le Tréport project failed to meet selection criteria. Winners of the 604 call for tender are Éolien Maritime France (EMF) for the Fécamp (498 MW), Courseulles605 sur-mer (450 MW) and Saint-Nazaire (480 MW) projects and Ailes Marines S.A.S for the 606 Saint-Brieuc project (500 MW). EMF, whose main shareholders are EDF Energies Nou607 velles and Dong Energy Power (a Danish energy company), uses wind turbines supplied 608 by Alstom. Ailes Marines SAS, whose main shareholders are Iberdrola and Eole-Res SA, 609 works with wind turbines supplied by Areva. It has also set up a partnership with Technip 610 and STX (MEDDE, 2014). In March 2013, the second call for tender for an additional 1 611 GW of offshore wind in Dieppe-Le Tréport (500 MW) and Noirmoutier (Vendée départe612 ment, $500 \mathrm{MW}$ ) was annouced. GDF Suez in collaboration with Areva, Neoen Marine, 613 and EDP Renouvelable won this second call for tender.

\section{B.2 The Saint-Brieuc offshore wind project}

615 According to Iberdrola and Eole-Res (2012a) and Arfi et al. (2013), the project will 616 be performed in partnership with Neoen Marine for the development stage, Areva for 617 turbine construction and procurement, Technip for engineering and offshore installation, 618 RTE for network connection, and Nass \& Wind for the identification and the development of manufacturing sites. In Table B.1, we give some characteristics of the project.

Table B.1 - Some characteristics of the Saint-Brieuc offshore wind project. Source: Iberdrola and Eole-Res (2012a), Iberdrola and Eole-Res (2012b) and AREVA (2012)

\begin{tabular}{lll}
\hline Site characteristics & Number value & Comment \\
\hline Average wind speed & $8.5 \mathrm{~m} / \mathrm{s}$ & - \\
Annual production & $1750 \mathrm{GWh} /$ year & Brittany \\
Equivalent power & 3500 hours & - \\
Loading factor & $40 \%$ & - \\
Availability & $93 \%$ & of the time \\
Distance from the coast & $17 \mathrm{~km}$ a & $80 \%$ more than $20 \mathrm{~km}$ \\
Average depth & $34 \mathrm{~m}$ & - \\
Minimum distance between rows & $1 \mathrm{~km}$ & - \\
Commissioning date & 2020 & - \\
Date of dockyard completion & 2020 & - \\
Lifetime: O\&M & 20 years : from 2020 to & - \\
Avoided $\mathrm{CO}_{2}$ emissions & 2040 & - \\
Cost of installing $1 \mathrm{MW}$ & 488,800 tons p.a. & - \\
\hline
\end{tabular}

a. For the first offshore turbine. 

technologies

Table C.1 - Methodologies used for assessing economic impacts of renewable energy technologies - Non-technical

\begin{tabular}{|c|c|c|c|c|c|c|}
\hline \multirow[b]{3}{*}{ Reference } & \multicolumn{6}{|c|}{ Methodologies } \\
\hline & \multicolumn{4}{|c|}{ Macro-economic modelling methodologies } & \multicolumn{2}{|c|}{ Analytical methodologies } \\
\hline & I-O model & CGE model & M-E model & Econometric regression & Surveys & Other recorded data \\
\hline Blazejczak et al. $(2014)$ & & & $\mathrm{x}$ & & & \\
\hline Coffman and Bernstein (2014) & & $\mathrm{x}$ & & & & \\
\hline Simas and Pacca (2014) & $\mathrm{x}$ & & & & & $\mathrm{x}^{35}$ \\
\hline Markaki et al. (2013) & $\mathrm{x}$ & & & & & \\
\hline Wang et al. $(2013)$ & $x^{36}$ & & & & & $\mathrm{x}^{36}$ \\
\hline Böhringer et al. (2013) & & $\mathrm{x}$ & & & & \\
\hline Llera et al. $(2013$ & & & & & & $x^{37}$ \\
\hline Oliveira et al. $(2013)$ & $\mathrm{x}$ & & & & & \\
\hline Brown et al. $(2012)$ & & & & $\mathrm{x}$ & & \\
\hline Lehr et al. (2012) & & & $\mathrm{x}$ & & & \\
\hline Collins et al. $(2012)$ & $\mathrm{x}$ & & & & & \\
\hline Lambert and Silva (2012) & $\mathrm{x}$ & & & & $\mathrm{x}$ & \\
\hline Slattery et al. $(2011)$ & $\mathrm{x}$ & & & & & \\
\hline Tourkolias and Mirasgedis (2011) & $\mathrm{x}$ & & & & & \\
\hline Mukhopadhyay and Thomassin (2011) & $\mathrm{x}$ & & & & & \\
\hline Cai et al. $(2011)$ & $\mathrm{x}$ & & & & & $\mathrm{x}^{36}$ \\
\hline Sastresa et al. (2010) & & & & & & $\mathrm{x} 37$ \\
\hline Wei et al. 2010 & & & & & & $x^{38}$ \\
\hline
\end{tabular}

35. Bibliographical review, expert opinions, data collection from reviews and interviews conducted for wind power plant managers, O\&M technicians, representatives of six wind turbine component manufacturers, project managers and environmental agencies.

36. An I-O model is used to calculate indirect jobs and analytical methodology to determine direct jobs.

37. The method employed relies on the collection and critical analysis of the results obtained based on primary information sources. The model design includes contributions taken from a prior analysis of the existing assessment methods.

38. The methodology is based on an analytical job creation model applied for the US power sector and covering the period going from 2009 to 2030 . The model compiles data from 15 job studies dealing with renewable energy, energy efficiency, carbon capture and storage and nuclear power. 
Table C.1 - Complete the previous page

\begin{tabular}{|c|c|c|c|c|c|}
\hline \multirow[b]{3}{*}{ Reference } & \multicolumn{5}{|c|}{ Methodologies } \\
\hline & \multicolumn{3}{|c|}{ Macro-economic modelling methodologies } & \multicolumn{2}{|c|}{ Analytical methodologies } \\
\hline & I-O model & CGE model & Econometric regression & Surveys & Other recorded data \\
\hline Solar Foundation 2010 & & & & $\mathrm{x}$ & \\
\hline Caldés et al. $(2009)$ & $\mathrm{x}$ & & & & \\
\hline Blanco and Rodrigues (2009) & & & & $\mathrm{x}$ & \\
\hline EWEA 2009a & & & & $\mathrm{x}$ & \\
\hline$\overline{\mathrm{DG} E T}(\overline{2009})$ & $\mathrm{x}$ & & & & \\
\hline Lehr et al. (2008) & $\mathrm{x}$ & & & $\mathrm{x}$ & \\
\hline Pollin et al. $(2008)$ & $\mathrm{x}$ & & & & \\
\hline Neuwahl et al. $(2008$ & $\mathrm{x}$ & & & & \\
\hline Moisan and Chêne $(\overline{2008)}$ & & & & & $\mathrm{x}^{39}$ \\
\hline AEE $(2008$ & $\mathrm{x}^{40}$ & & & $x 40$ & $\mathrm{x}$ \\
\hline Thornleya et al. (2008) & & & & & $x^{42}$ \\
\hline DWEA $(2008)$ & & & & $\mathrm{x}$ & \\
\hline Moreno and Lopez $(2008$ & & $\mathrm{x}$ & & & $\mathrm{x} 43$ \\
\hline European Parliament $(2007)$ & & & & & $\mathrm{x}{ }^{44}$ \\
\hline Madlener and Koller (2007) & $\mathrm{x}$ & & & & \\
\hline Hillebrand et al. $(2006)$ & & $\mathrm{x}$ & & & \\
\hline FMENCNS-BMU $(2006)$ & $\mathrm{x}$ & & & $\mathrm{x}$ & \\
\hline Pfaffenberger et al. $(\overline{2006})$ & & & & & $x^{44}$ \\
\hline Pedden & & & & & $x^{44}$ \\
\hline
\end{tabular}

39. Net production and employment ratios (imports were ignored).

40. Indirect employment was calculated on the basis of questionnaires and the subsequent modification of the I-O table. .

41. Analysis of annual reports and information from the government tax office.

42. First, authors developed a staffing pattern for each plant based on a technical appraisal of its operational requirements. Then, they quantified jobs related to the development and construction of the plant (which are available only for a fixed period) based on experience and consultation.

43. Regional information was provided by the Regional Energy Foundation and the Spanish Renewable Energy Development Plan $2000-2010$.

44. Non econometric meta-analysis. 


\section{Brief technical presentation of the Leontief model (1986)}

623 We differentiate between the open and the closed Leontief models (1986):

624

625

626

\section{D.1 The open Leontief model (1986)}

The starting point of the closed Leontief model (1986) is the supply-demand equilibrium relationship described as follows:

$$
X=Z i+Y,
$$

627

where $X$ is the $n$-vector ${ }^{45}$ of production, $Z$ the $(n \times n)$ matrix of intermediate consumption, $i$ the $n$-vector composed only of the number 1 , and $Y$ the $n$-vector of final demand which integrates final consumption ${ }^{46}$, the gross capital formation, inventory change, and exports. The model defines an $(n \times n)$ matrix of technical coefficients $A$ indicating the monetary amount of inputs required to produce one monetary unit. It is calculated as follows:

$$
A=Z X^{-1}
$$

Leontief's model (1986) assumes that the technical coefficients are stable. Therefore, inputs are assumed to be complementary and the model does not allow for the integration of innovation effects in the production processes. Moreover, the stability of technical coefficients implies that scale effects are constant.

Incorporating equation $(\mathrm{D} .2$ into equation $\mathrm{D} .1$ gives:

$$
X=A X+Y
$$

After re-arrangement and factorization, we obtain

$$
X=(I-A)^{-1} Y=B Y
$$

where $B=(I-A)^{-1}$ is the $(n \times n)$ inverse Leontief matrix and $I$ the identity matrix.

The inverse Leontief matrix is the core element of the Leontief model (1986). It links the production vector $X$ to the final demand vector $Y$ by indicating the total (direct and indirect) production required to satisfy one monetary unit of the final demand. The different elements of the inverse matrix of Leontief $b_{i j}$ indicate the required value of production of different industries $i$ to satisfy one monetary unit of demand for the product $j$. By summing the rows $i$ for a column $j$ in matrix $B$, we obtain the production multipliers for product $j$ :

$$
O_{j}^{X}=\sum_{i=1}^{n} b_{i j}
$$

$$
\text { The production multipliers } O^{X} \text { are used to estimate the indirect impacts. }
$$

Equation (D.4) can be extended to incorporate added value and employment. Leontief's

45. $n$ represents the number of products within an economy.

46. The demand for final consumption comes from households, public administrations and non-profit institutions serving households. 
model (1986) assumes that the added value per unit of production is stable as indicated

649 in the following equation:

$$
V=\hat{v} X
$$

650 where $V$ is $n$-vector of the added value for industry $j$ and $v$ the $n$-vector of the added value 651 per unit of production for each industry $j$. The caret indicates that the matrix is diagonal.

652 By integrating equation (D.6) into equation (D.4), we obtain

$$
V=\hat{v}(I-A)^{-1} Y=\hat{v} B Y .
$$

The elements of matrix $\hat{v} B\left(v_{i} b_{i j}\right)$ indicate the total (direct and indirect) value added 654 of industry $j$ stemming from the demand of product $i$. By summing rows $i$ in column $j$ in 655 matrix $\hat{v} B$, we find the added-value multipliers for product $j$ :

$$
O_{j}^{V}=\sum_{i=1}^{n} v_{i} b_{i j}
$$

656 The same reasoning is adopted for employment. Leontief's model (1986) assumes that 657 the employment per unit of production is stable as indicated in the following equation:

$$
L=\hat{l} X
$$

658 where $L$ is $n$-vector of employment in industry $j$ and $l$ the $n$-vector of the employment per 659 monetary unit of production for each industry $j$. By integrating equation (D.9) into (D.4), 660 we obtain:

$$
L=\hat{l}(I-A)^{-1} Y=\hat{l} B Y .
$$

661 Elements of the matrix $\hat{l} B$, noted $\left(l_{i} b_{i j}\right)$, indicate the total (direct and indirect) employ662 ment in industry $j$ stemming from the demand of product $i$. By summing in the matrix $663 \hat{l} B$ the different rows $i$ for the column $j$, we obtain the employment multipliers for product $664 j$ :

$$
O_{j}^{L}=\sum_{i=1}^{n} l_{i} b_{i j} .
$$

\section{D.2 The closed Leontief model $(\overline{\mathbf{1 9 8 6}})$}

The closed Leontief model (1986) is an extension of the open model. It assumes that the household sector is endogenous ${ }^{47}$. Subsequently, to integrate the household sector, the vectors and matrix in equation (D.1) should be extended. The $(n \times n)$ matrix $Z$ becomes the $(n+1)(n+1)$ matrix $\bar{Z}$. It henceforth integrates an additional row corresponding to the household labour payment input $Z_{R}$ and an additional column corresponding to the

47. This assumption means that a household earns income in payment for its labour input. It spends this income for the consumption of goods and services. 
final consumption of households $Z_{C}$ :

$$
\bar{Z}=\left(\begin{array}{cc}
Z & Z_{C} \\
Z_{R} & 0
\end{array}\right) .
$$

Moreover, the $n$-vector $X$ becomes the $(n+1)$-vector $\bar{X}$ by integrating an additional row $X_{n+1}$ corresponding to household production that is equal to the total input from labour payment:

$$
\bar{X}=\left(\begin{array}{c}
X \\
X_{n+1}
\end{array}\right)
$$

666

667 The new $n$-vector of final demand $\bar{Y}$ excludes the vector of household final consumption 668 from the vector of final demand in the open model, because it is integrated in matrix $\bar{Z}$.

669 The supply-demand equilibrium is therefore written as follows:

$$
\bar{X}=\bar{Z} i+\bar{Y}
$$

670 The $(n+1)(n+1)$ matrix of technical coefficients is calculated as in the open model:

$$
\bar{A}=\overline{Z X}^{-1}
$$

671 By integrating equation (D.13) into equation (D.12), and after re-arrangement and 672 factorization, we obtain:

$$
\bar{X}=(I-\bar{A})^{-1} \bar{Y}=\overline{B Y},
$$

673 where $B=(I-\bar{A})^{-1}$ is the $(n \times n)$ inverse Leontief matrix. Its elements $\bar{b}_{i j}$ indicate 674 the value of production (direct, indirect and induced) of industry $j$ required to satisfy one 675 monetary unit of demand for product $i$. By summing rows $i$ in column $j$ in the matrix $\bar{B}$, 676 we find the production multipliers for product $j$ :

$$
O_{j}^{\bar{X}}=\sum_{i=1}^{n} \bar{b}_{i j} .
$$

677 By adopting the same reasoning as in the open model, it is possible to calculate the 678 added-value and employment multipliers:

$$
\begin{aligned}
& O_{j}^{V}=\sum_{i=1}^{n} v_{i} \bar{b}_{i j} \\
& O_{j}^{L}=\sum_{i=1}^{n} l_{i} \bar{b}_{i j} .
\end{aligned}
$$


Table E.1 - Overview of estimations of employment impact of the Saint-Brieuc offshore wind farm

\begin{tabular}{|c|c|c|c|}
\hline References & Topic & Methodology & Expected employment impact \\
\hline \begin{tabular}{|l|l|} 
Ailes $\quad$ Marines & SAS \\
$2014 \mathrm{c}$ & ${ }^{a}$
\end{tabular} & $\begin{array}{l}\text { Assessing employment impact of the Saint- } \\
\text { Brieuc offshore wind farm. }\end{array}$ & n.a. $b^{b}$ & $\begin{array}{l}\text { - } 2000 \text { direct FTE jobs are expected in western France ( } 1860 \text { specific to manu- } \\
\text { facturing and installation and } 140 \text { to O\&M) among which } 1000 \text { are expected in } \\
\text { Brittany. }\end{array}$ \\
\hline \begin{tabular}{|l|l|l|} 
CCICA 2011, & \\
\end{tabular} & $\begin{array}{l}\text { Assessing the employment impact of the } \\
\text { Saint-Brieuc offshore wind farm. }\end{array}$ & n.a. & $\begin{array}{l}\text { - Oxford Economics } 2010): 95 \text { to } 125 \text { FTE jobs are expected during the O\&M } \\
\text { phase. } \\
\text { EWEA (2009a): } 5500 \text { FTE jobs are expected among which } 150 \text { are specific to } \\
\text { O\&M. } \\
\text { - European Commission (2001): } 2010 \text { to } 2250 \text { FTE jobs are expected, among } \\
\text { which } 30 \text { are specific to O\&M. } \\
\text { Bretagne Pôle Naval (BPN): } 2500 \text { FTE jobs are expected, among which between } \\
60 \text { to } 80 \text { are specific to O\&M. }\end{array}$ \\
\hline Nass\&Wind 2011) d & $\begin{array}{l}\text { Assessing the employment impact of the } \\
\text { Saint-Brieuc offshore wind farm. }\end{array}$ & n.a. & $\begin{array}{l}2000 \text { direct FTE jobs are expected during manufacturing and installation and } \\
60 \text { during O\&M. }\end{array}$ \\
\hline
\end{tabular}

a. Estimations quoted in this reference have been also cited in the local press (see Ouest France (2014)).

b. Not available.

c. CCICA (2011) presents a compilation of estimations of employment impacts of the Saint-Brieuc offshore wind project based on Oxford Economics (2010), EWEA (2009a), European Commission (2001) and Bretagne Pôle Naval (BPN). We note that bibliographic details of the European Commission (2001) and Bretagne Pôle Naval are not available in CCICA (2011). Therefore, the methodologies used to estimate the number of jobs are unknown. The methodologies used in Oxford Economics (2010) and EWEA (2009a) are presented in Table E.2.

d. Quoted in CEICA (2011). 
Table E.2 - Overview of studies assessing the economic impacts of overseas offshore wind farms

\begin{tabular}{|c|c|c|c|}
\hline References & Topic & Country & Methodology \\
\hline $\begin{array}{l}\text { Sercy et al. } \\
2014\end{array}$ & $\begin{array}{l}\text { Assessing economic and } \\
\text { fiscal impacts of a } 40 \mathrm{MW} \\
\text { offshore wind farm off the } \\
\text { coast of South Carolina } \\
\text { from } 2016 \text { to } 2036 \text {. }\end{array}$ & US & $\begin{array}{l}\text { Policy Insight PI+ economic modelling engine (Regional } \\
\text { Economic Models, Inc. (REMI)). It is an input-output and } \\
\text { computable general equilibrium-based model as well as a } \\
\text { new economic geography model. Economic impacts are } \\
\text { estimated using employment, total compensation, output, } \\
\text { net state or local government revenue, and direct, indirect } \\
\text { and induced impacts } 48 \text {. }\end{array}$ \\
\hline $\begin{array}{|ll|}\text { US } & \text { DE } \\
2013 & \end{array}$ & $\begin{array}{l}\text { Assessing economic im- } \\
\text { pacts of offshore wind } \\
\text { developments in Georgia, } \\
\text { South Carolina, North } \\
\text { Carolina, and Virginia. }\end{array}$ & US & $\begin{array}{l}\text { Jobs and Economic Development Impact (JEDI) model } \\
\text { based on an input-output methodology } 49 \text {. Economic im- } \\
\text { pacts are estimated using employment, earning and out- } \\
\text { put as metrics. The model estimates gross impacts which } \\
\text { are distributed across three categories namely project de- } \\
\text { velopment and on-site labour impacts, local revenue and } \\
\text { supply chain impacts, and induced impacts. }\end{array}$ \\
\hline
\end{tabular}

- In 2016, during the construction and the manufacture of components, creation of 959 direct, indirect and induced jobs, $\$ 46.3 \mathrm{M}$ in wages, and $\$ 148.4 \mathrm{M}$ in output is expected.

- During the O\&M phase (2017-2037), annual creation of 10 direct, indirect and induced jobs, $\$ 934,000$ in wages, and $\$ 2.8$ $\mathrm{M}$ in output is expected.

- In 2020, during which $25 \%$ of the supply chain investment will be carried out locally, $252 \mathrm{MW}$ are expected to induce 4220 FTE jobs during the construction phase and 410 annual FTE jobs during the O\&M phase.

- In 2030, when $62 \%$ of the supply chain investment will be carried out locally, $4027 \mathrm{MW}$ are expected to induce 20,100 FTE jobs during the construction phase and 6700 annual FTE jobs during O\&M phase 50 .

\begin{tabular}{|c|c|c|}
\hline $\begin{array}{l}\text { Zammit } \\
\text { and Miles } \\
(2013) .\end{array}$ & $\begin{array}{l}\text { Assessing economic im- US } \\
\text { pacts of offshore wind } \\
\text { development in Georgia, } \\
\text { South Carolina, North } \\
\text { Carolina, and Virginia. }\end{array}$ & $\begin{array}{l}\text { Jobs and economic development impact (JEDI) model } \\
\text { based on input-output methodology } 49 \text { The model was } \\
\text { built around three variables: market and deployment, re- } \\
\text { gional investment and cost. For each variable, three de- } \\
\text { velopment paths were considered. Three scenarios run- } \\
\text { ning from } 2020 \text { to } 2030 \text { were generated: the first assumes } \\
\text { a small offshore industry with limited regional investment, } \\
\text { the second supposes moderate growth of the offshore wind } \\
\text { industry and the third considers fast development of the } \\
\text { industrv. }\end{array}$ \\
\hline
\end{tabular}

- During the construction phase, 19 to 39 FTE jobs per MW would be created depending on the rate of the regional development of the supply chain 51 .

- During the O\&M phase, 1.64 to 1.67 FTE jobs per MW would be created.

- As the industry grows, projected earnings and outputs are higher.

\footnotetext{
48. More details on the model are available on www.remi.com.

49. More details on the JEDI model are available on www.nrel.gov/analysis/jedi/ and in Lantz et al

50. These results are relative to a scenario which considers a moderate deployment of offshore wind.

51. Regional development of the supply chain supports more jobs per MW.
} 
Table E. 2 - Complete the previous page

\begin{tabular}{|c|c|c|c|}
\hline References & Topic & Country & Methodology \\
\hline Colbert- & \multirow{4}{*}{$\begin{array}{l}\text { Assessing economic im- } \\
\text { pacts of } 1000 \mathrm{MW} \text { of off- } \\
\text { shore wind industry in } \\
\text { South Carolina. Assessing } \\
\text { fiscal impacts of existing } \\
\text { wind energy supply chain }\end{array}$} & \multirow[t]{4}{*}{ US } & \multirow{4}{*}{$\begin{array}{l}\text { The regional dynamics (REDYN) economic modelling en- } \\
\text { gine based on a social accounting matrix (SAM) and input- } \\
\text { output functions derived from sector relationships revealed } \\
\text { in the SAM. Those relationships provide a framework for } \\
\text { defining equilibrium processes in the model's computable } \\
\text { general equilibrium functions } 52 \text {. }\end{array}$} \\
\hline Busch et al. & & & \\
\hline$(2012)$ & & & \\
\hline & & & \\
\hline
\end{tabular}

Results

- Between 2016 and 2025, the manufacture of wind turbine components will annually generate 293 direct, indirect and induced jobs, $\$ 18.3 \mathrm{M}$ in wages, $\$ 54.9 \mathrm{M}$ in output, and $\$ 5.7$ $\mathrm{M}$ in combined state and local government revenue. Installation would annually generate an annual average of 3329 direct, indirect and induced jobs, $\$ 163.1 \mathrm{M}$ in wages, $\$ 270.7$ $\mathrm{M}$ in output, and $\$ 51.2 \mathrm{M}$ in combined state and local government revenue.

- Between 2026 and 2030, the O\&M are expected to generate annually 678 direct, indirect and induced jobs, $\$ 41.8 \mathrm{M}$ in wages, $\$ 115.2 \mathrm{M}$ in output, and $\$ 13.4 \mathrm{M}$ in combined state and local government revenue.

\begin{tabular}{lll}
\hline Oxford & $\begin{array}{l}\text { Assessing employment im- } \\
\text { pacts of the O\&M phase } \\
\text { of }\end{array}$ & $\begin{array}{l}\text { Economics } \\
\text { the UK in } 2010 \text { and } 2020 .\end{array}$
\end{tabular}

\section{UK Input-output methodology.}

- In 2010, a total installed capacity of $1 \mathrm{GW}$ engenders about 450 jobs among which 290 are direct and 160 indirect and induced.

- An expected installed capacity equal to $20.5 \mathrm{GW}$ by 2020 would induce about 7230 jobs among which 4000 are direct, 1660 indirect and 1570 induced.

\begin{tabular}{|c|c|c|c|}
\hline EWEA & $\begin{array}{l}\text { Assessing employment im- } \mathrm{EU} \\
\text { pacts wind energy in the } \\
\mathrm{EU}{ }^{53} \text {. }\end{array}$ & $\begin{array}{l}\text { Data collection based on surveys. Modelling exercise using } \\
\text { scenario projection. }\end{array}$ & $\begin{array}{l}\text { - During development, manufacturing and installation: } 15.1 \\
\text { direct and indirect jobs per new MW are expected; } \\
\text { - During O\&M: } 0.33 \text { direct and indirect jobs per (cumulative) } \\
\text { MW are expected. }\end{array}$ \\
\hline
\end{tabular}

continued on next page

52. More details on the REDYN model are available on http://www.redyn.com/.

53. This reference deals with both onshore and offshore wind energy. 
Table E.2 - Complete the previous page

\begin{tabular}{|c|c|c|c|c|}
\hline References & Topic & Country & Methodology & Results \\
\hline $\begin{array}{l}\text { Boettcher } \\
\text { et al. } \\
2008 \text {, }\end{array}$ & $\begin{array}{l}\text { Assessing the employment } \\
\text { impacts of wind } 53 \text {, wave } \\
\text { and tidal industries in the } \\
\text { UK by } 2020 \text {. }\end{array}$ & UK & $\begin{array}{l}\text { Employment model based on five input variables namely } \\
\text { capacity, labour intensity, cost reduction, local content, } \\
\text { and export market share. The model calculates employ- } \\
\text { ment split into technologies, regions, and export and do- } \\
\text { mestic markets along the value chain. The evolution of } \\
\text { employment is captured by a scenario engine. }\end{array}$ & $\begin{array}{l}\text { - An installed onshore and offshore wind capacity of } 27 \mathrm{GW} \\
\text { would generate } 30,000 \text { jobs } 54 \\
\text { - An installed offshore capacity of } 20 \mathrm{GW} \text { would induce } 6734 \\
\text { jobs during the O\&M } 5 \text {. }\end{array}$ \\
\hline $\begin{array}{l}\text { Carbon } \\
\text { Trust } \\
2008 \text {, }\end{array}$ & $\begin{array}{l}\text { Assessing how much off- } \\
\text { shore wind power capac- } \\
\text { ity could reasonably be re- } \\
\text { quired to help the UK } \\
\text { reach the } 2020 \text { renewable } \\
\text { energy target and what } \\
\text { would be required to de- } \\
\text { liver needed wind capacity } \\
\text { cost effectively }\end{array}$ & UK & n.a. & $\begin{array}{l}\text { - The UK will need to install } 29 \mathrm{GW} \text { of offshore wind to reach } \\
\text { the } 2020 \text { renewable energy target. Between } 40,000 \text { to } 70,000 \\
\text { jobs and } £ 6 \mathrm{M} \text { to } £ 8 \mathrm{M} \text { in annual revenues are consequently } \\
\text { expected } 56 \text { Jobs will be distributed as follows: } \\
\text { - } 3000 \text { to } 4000 \text { in R\&D, engineering, and design; } \\
\text { - } 7000 \text { to } 15000 \text { in turbine and component manufacturing; } \\
\text { - } 22,000 \text { in services; } \\
\text { - } 8000 \text { to } 29,000 \text { in installation } 57 \text { and O\&M. }\end{array}$ \\
\hline $\begin{array}{l}\text { GWEC } \\
2008)^{58}\end{array}$ & $\begin{array}{l}\text { Global wind energy out- } \\
\text { look for } 200853 \text { ? }\end{array}$ & Global & n.a. & $\begin{array}{l}\text { - During development, manufacturing, and installation: } 11 \text { to } \\
\text { 15.1 direct and indirect jobs per additional MW are expected; } \\
\text { - During O\&M: } 0.33 \text { direct and indirect jobs per (cumulative) } \\
\text { MW are expected } 59\end{array}$ \\
\hline
\end{tabular}

continued on next page

54. More details about the distribution of this number are not available.

55. Quoted in BWEA (2010) and Oxford Economics (2010).

56. Depending on the level of government involvement to support offshore wind industry.

57. Includes indirect jobs related to the installation and construction of turbines, foundations, substations and grid connections.

58. Quoted in EWEA (2009a).

59. Cited numbers represent assumptions used in GWEC 2008) for scenario construction for Germany, Denmark, Spain, and the Netherlands. 
Table E. 2 - Complete the previous page

\begin{tabular}{|c|c|c|c|c|}
\hline References & Topic & Country & Methodology & Results \\
\hline \begin{tabular}{l|} 
Flynn and \\
Carey \\
2007,
\end{tabular} & $\begin{array}{l}\text { Assessing economic and } \\
\text { fiscal impacts for South } \\
\text { Carolina from } 480 \text { MW of } \\
\text { installed capacity of off- } \\
\text { shore wind. }\end{array}$ & US & $\begin{array}{l}\text { An economic impact model with scenarios projection de- } \\
\text { pending on the level of regional involvement of South Car- } \\
\text { olina in the manufacture and assembly of turbine genera- } \\
\text { tors. }\end{array}$ & $\begin{array}{l}\text { - } 1881 \text { direct, indirect, and induced FTE jobs are expected; } \\
\text { - An increase of annual output by } \$ 287 \mathrm{M} \text { and of annual dis- } \\
\text { posable income by up to } \$ 93 \mathrm{M} \text { are expected; } \\
\text { - An increase in income tax revenues of up to } \$ 2.8 \mathrm{M} \text { and in } \\
\text { corporate income tax revenues of up to } \$ 190,000 \text { over the } 2 \text { - } \\
\text { year period of manufacturing and installation are expected. }\end{array}$ \\
\hline
\end{tabular}


682 AEE. Estudio macroeconómico del impacto del sector eólico en españa, 2008. Asociación 683 Empresarial Eólica (AEE). Elaborated by Deloitte.

684 Ailes Marines SAS. Appel d'offres éolien en mer. Ambitions et expertises pour une fil685 ॥ ière industrielle française, 2012. URL wWw.edf-energies-nouvelles.com/_[Accessed_ 686 November_05,_2014]. EDF EN, DONG Energy, WPD, Nass\&Wind, ALSTOM. 9 p.

687 Ailes Marines SAS. Projet éolien en mer de la Baie de Saint Brieuc. 688 Le dossier du maître d'ouvrage. Débat public mars - juillet 2013, 2013a. 689 uRL http://www.developpement-durable.gouv.fr/Dossier-de-presse-Vers-un690 nouveau.html_[Accessed_November_05,_2014]. $132 \mathrm{p}$.

691 Ailes Marines SAS. Un projet industriel : le coût et le financement, 2014a. URL www.http: 692 //http://www.eolienoffshoresaintbrieuc.com_[Accessed_October_08,_2014].

693 Ailes Marines SAS. Un projet industriel : le calendrier du projet, 2014b. URL www.http: 694 //http://www.eolienoffshoresaintbrieuc.com_[Accessed_May_10,_2016].

695 Ailes Marines SAS. Un projet industriel : les emplois mobilisés, 2014c. URL www.http: 696 //http://www.eolienoffshoresaintbrieuc.com_[Accessed_October_08,_2014].

697 Ailes Marines SAS. Un projet industriel : la fabrication des éléments constitutifs du parc, 698 a 2014d. URL wWw.http://http://www.eolienoffshoresaintbrieuc.com_[Accessed_ 699 May_10,_2016]

700 AREVA. Éolien en mer : création d'une filière industrielle en Bretagne et en Normandie.

701 Rencontre entreprises - Langueux, 2012. URL http://www.bretagne.cci.fr/files/ 702 a crci_bretagne/Actualites/2012juin/AREVA-Rencontre-entreprises-Langueux703 290512-VF.pdf_[Accessed_September_03,_2014].

704 B. Arfi, R. Berrada, T. Deffains, and A. Mercat. Territorialisation de l'éolien offshore dans 705 la Baie de Saint Brieuc, 2013. Projet Sciences Humaines. INSA Rennes et SciencesPo 706 Rennes.

707 M. I. Blanco. The economics of wind energy. Renewable and Sustainable Energy Reviews, $708 \quad 13(6-7): 1372-1382,2009$.

709 M. I. Blanco and G. Rodrigues. Direct employment in the wind energy sector: an EU 710 study. Energy Policy, 37:2847-2857, 2009.

711 J. Blazejczak, F. G. Braun, D. Edler, and W. P. Schill. Economic effects of renewable 712 energy expansion: a modelsed analysis for Germany. Renewable and Sustainable Energy 713 Reviews, 40:1070-1080, 2014.

714 M. Boettcher, N. P. Nielsen, and K. Petrick. A closer look at the development 715 of wind, wave \& tidal energy in the UK. Employment opportunities and chal716 lenges in the context of rapid industry growth, 2008. URL http://www.bain.com/ 
publications/articles/employment-opportunities-and-challenges-in-thecontext-of-rapid-industry-growth.aspx_[Accessed_October_13,_2014]. Bain \&

719 Compagny.

C. Böhringer, A. Keller, and E. Van der Werf. Are green hopes too rosy? Employment and welfare impacts of renewable energy promotion. Energy Economics, 36:277-285, 2013.

A. Bonfiglio and F. Chelli. Assessing the behaviour of non-survey methods for constructing regional input-output tables through a Monte Carlo simulation. Economic Systems Research, 20:243-258, 2008.

BPN. Éolien offshore posé. Besoins industriels des donneurs d'ordre et offre des enn treprises de la région Bretagne, 2011. URL www.themavision.fr_[Accessed_October_ 14,_2014]. GL Garrad Hassan pour Bretagne Pôle Naval.

BPN. Les entreprises de l'industrie éolienne offshore en Bretagne. Annuaire 2012, 2012. URL www.bretagnepolenaval.org_[Accessed_October_13,_2014]. Bretagne Pôle Naval.

J. P. Brown, J. Pender, R. Wiser, E. Lantz, and B. Hoen. Ex post analysis of economic impacts from wind power development in US counties. Energy Economics, 34:1743-1754, 2012.

BWEA. What does the Round 3 announcement mean?, 2010. British Wind Energy Association.

W. Cai, C. Wang, J. Chen, and W. S. Green economy and green jobs: myth or reality? The case of China's power generation sector. Energy, 36(10):5994-6003, 2011.

N. Caldés, M. Varela, M. Santamaria, and R. Sáez. Economic impact of solar thermal electricity deployment in Spain. Energy Policy, 37:1628-1636, 2009.

Carbon Trust. Offshore wind power: big challenge, big opportunity. Maximising the environmental, economic and security benefits, 2008. URL

CCICA. Projet de parc éolien offshore de la baie de Saint-Brieuc. Rapport final du groupe q de travail "Éolien offshore", 2011. URL http://www.exceltys.com/article/photo/ dossier645/GT_EOLIEN_OFFSHORE2011VF.pdf_[Accessed_September_05,_2014]. Chambre de l'Industrie de du Commerce des Côtes d'Armor (CCICA). 63 p.

CESER. Des énergies marines en Bretagne (2) : Concrétisons la filière, 2012. URL 1] http://www.bretagne.fr/internet/jcms/preprod_162352/des-energies-marinesen-bretagne-concretisons-la-filiere_[Accessed_November_05,_2014]. Conseil Économique, Social et Environnemental de Bretagne (CESER). 228 p.

M. Coffman and P. Bernstein. Linking hawaii's islands with wind energy. Annals of Regional Science, DOI 10.1007/s00168-014-0644-y, 2014. 
E. Colbert-Busch, R. T. Carey, and E. W. Seltzman. South Carolina

755 wind energy supply chain survey and offshore wind economic impact study,

756 2012. URL http://sti.clemson.edu/reports/cat_view/293-regional-economic-

757 analysis-laboratory_[Accessed_October_17,_2014]. Clemson University. Retora-

758 tion Institute. Clemson-Strom Thurmond Institute.

759 A. R. Collins, E. Hansen, and M. Hendryx. Wind versus coal: comparing the local economic 760 impacts of energy resource development in Appalachia. Energy Policy, 50:551-561, 2012.

761 CRE. Cahier des charges de l'appel d'offres $n^{\circ}$ 2011/s 126-208873 portant sur des in762 stallations éoliennes de production d'électricité en mer en France métropolitaine, 2011.

763 URL http://www.cre.fr/documents/appels-d-offres/appel-d-offres-portant-

764 sur-des-installations-eoliennes-de\discretionary $\{-\}\{\}\{\}$ production-d-

765 electricite-en-mer-en-france-metropolitaine. Commission de Régulation de

766 l'Énergie (CRE). Ministère de l'Écologie, du Développement durable, des Trasnports et

767 du Logement. Ministère de l'Économie des Finances et de l'Industrie. 80 p.

768 CRE. Journal officiel de la République française. Commission de Régulation de l'Énergie 769 (CRE), Avril 2012. URL http://energie2007.fr/images/upload/jo_28042012_ delib_cre_1.pdf.

771 DG ET. The impact of renewable energy policy on economic growth and employment in 772 the European Union, 2009. URL http://ec.europa.eu/energy/renewables/studies/

\section{doc/renewables/2009_employ_res_summary.pdf_[Accessed_December_23,_2014].}

DG Energy and Transport.

M. H. Duong, F. Ghersi, and R. Thello. Les effets en emploi d'un captage et stockage du CO2 en France. une étude macroéconomique comparée avec les énergies renouvelables, 2009. Centre Internatinale de Recherche sur l'Environnement et le Développement (CIRED). Rapport SOCECO 2.

DWEA. Environmental and employment benefits of wind, 2008. URL www.windpower. org_[Accessed_December_23,_2014]. Danish Wind Energy Association DWEA.

ESA. European system accounts 2010, 2010. URL http://ec.europa.eu/eurostat/ a documents/3859598/5925693/KS-02-13-269-EN.PDF/44cd9d01bc64-40e5-bd40d17df0c69334.

European Commission, International Montery Fund, Organisation for Economic Cooperation and Development, United Nations, and World Bank . System of national accounts 2008, 2009. ISBN 978-92-1-161522-7. 722 p.

European Parliament. Employment potential of renewable forms of energy and increased efficiency of energy use, 2007. Briefing note. DG Internal Policies of the Union. Policy department: Economic and Scientific Policy. IP/A/EMPL/FWC/2006-03/SC3.

90 Eurostat. Eurostat manual of supply, use and input-output tables, 2008. URL a http://epp.eurostat.ec.europa.eu/portal/page/portal/eurostat/home/ 
794 Eurostat. Energy statistics - main indicators, 2014a. URL http://ec.europa.eu/ eurostat/web/energy/data/database_[Accessed_December_17,_2014]

796 Eurostat. ESA supply, use and input-output tables, 2014b. URL http: 797 //ec.europa.eu/eurostat/web/esa-supply-use-input-tables/data/workbooks_

798 [Accessed_December_21,_2015].

799 EWEA. The economics of wind energy, 2009a. URL http://www.ewea.org/_[Accessed_ 800 October_11,_2014]. European Wind Energy Association (EWEA).

801 FEM. Présentation stratégique de France Énergies Marines. France Énergies Marines 802 (FEM). Version B, 2011. Plouzané.

803 A. T. Flegg and T. Tohmo. Regional input-output models and the FLQ formula: a case 804 study of Finland, 2008. Economics discussion paper series N8/08. School of Economics, 805 University of the West of England.

806 A. T. Flegg and C. D. Webber. On the appropriate use of location quotients in generatin807 gregional input-output tables: reply. Regional studies, 31:795-805, 1997.

808 A. T. Flegg, C. D. Webber, and M. V. Elliott. On the appropriate use of location quotients 809 in generating regional input-output tables. Regional studies, 31:58-86, 1995.

810 R. G. Flynn and R. T. Carey. The potential economic impact of an offshore wind farm to 811 the State of South Carolina, 2007. URL http://www . of fshorewindhub.org/resource/ 812 1000_[Accessed_0ctober_13,_2014]. The Strom Thurmond Institute.

813 FMENCNS-BMU. Renewable energy: employment effects. Impact of the expansion of 814 a renewable energy on the German labour market, 2006. URL http://www.bmu.de/ 815 english/_[Accessed_December_23, _2014]. Federal Ministry for the Environment, Na816 ture Conservation and Nuclear Safety (FMENCNS) - BMU.

817 H. Garrett-Peltier. Green versus brown: Comparing the employment impacts of energy 818 efficiency, renewable energy, and fossil fuels using an input-output model. Economic $819 \quad$ Modeling, 61:439-447, 2017.

820 G. Gautier. Énergies marines renouvelables. Emplois, compétences, formation : quelles 821 perspectives d'avenir?, 2010.

822 GL BPN. Éolien offshore posé : besoins industriels des donneurs d'ordre et offre des 823 entreprises de la région Bretagne. GL Garrad Hassan et Bretagne Pôle Naval (BPN), 824 2011. 29 p.

825 GWEC. Global wind energy outlook 2008, 2008. URL http://www.gwec.net/ 826 publications/global-wind-energy-outlook/gweo-2008/_[Accessed_October_15, 827 _2014]. Global Wind Energy Council (GWEC). 

energies and employment effects in Germany. Energy Policy, 34:3484-3494, 2006.

830 Iberdrola and Eole-Res. Le projet éolien en mer en Baie de Saint-Brieuc : un projet 831 a breton de territoire durable. Mai 2012a. URL http://www.bretagne.cci.fr/files/ 832 a crci_bretagne/Actualites/2012juin/PrAsentation-BG-rencontre-industriels833 120529-VF.pdf_[Accessed_June_05,_2014]. Rencontres avec les industriels bretons. 834 Langueux.

835 Iberdrola and Eole-Res. Le projet éolien en mer en Baie de Saint-Brieuc : un projet breton 836 de territoire durable. Mai 2012b. URL http://www.bretagne.cci.fr/files/crci_ 837 bretagne/Actualites/2012juin/PrAsentation-BG-CBE-120529-VF.pdf_[Accessed_ 838 June_08,_2014]. $7^{\text {ième }}$ conférence bretonne de l'énergie. Saint-Brieuc.

839 IHS EER. Global offshore wind energy market and strategies 2010 - 2025. 840 November 2010. URL http://www.emerging-energy.com/uploadDocs/Excerpt_ 841 GlobalOffshoreWindEnergyMarketsandStrategies2010.pdf. IHS Emerging Energy 842 Research. 6 p.

843 INSEE. Données de recensement de la population 2011. emploi au lieu de travail en 844 口 2011, 2011. URL http://www.insee.fr/fr/themes/detail.asp?reg_id=99\&ref_id= 845 td-emploi-lieu-travail-11_[Accessed_January_01,_2014]. Fichier EMP2 emploi 846 au lieu du travail par sexe, statut et secteur d'activité économique.

847 IRENA. Innovation outlook - offshore wind, 2016. URL https://www.irena.org/ 848 口. DocumentDownloads/Publications/IRENA_Innovation_Outlook_Offshore_Wind_ 849 2016.pdf_[Accessed_March_27,_2017]

850 C. M. Johnstone, D. Pratt, J. A. Clarke, and A. D. Grant. A techno-economic analysis of 851 tidal energy technology. Energy, 49:101-106, 2013.

852 M. Junginger, A. Faaij, and W. C. Tunkenburg. Cost reduction prospects for offshore wind 853 farms. Wind engineering, 28(1):97-118, 2004.

854 R. J. Lambert and P. P. Silva. The challenges of determining the employment effects of 855 renewable energy. Renewable and Sustainable Energy Reviews, 16:4667-4674, 2012.

856 E. Lantz, M. Goldberg, and D. Keyser. Jobs and Economic Development Impact (JEDI) 857 model: offshore wind user reference guide, 2013. URL www.nrel.gov/publications_ 858 [Accessed_October_17,_2014]. Technical Report. National Renewable Energy Labo859 ratory NREL/TP-6A20-58389. Contract No. DE-AC36-08GO28308.

860 U. Lehr, J. Nitsch, M. Kratzat, C. Lutz, and D. Edler. Renewable energy and employment 861 in Germany. Energy Policy, 36:108-117, 2008.

862 U. Lehr, C. Lutz, and D. Edler. Green jobs? Economic impacts of renewable energy in 863 Germany. Energy Policy, 47:358-364, 2012. 
W. Leontief and A. Strout. Structural independence and economic development, chapter Multiregional input-output analysis, pages 119-149. 1963. London: Macmillan. Reprint in Leontief W. (1986), Input-output economics, Oxford University Press, USA.

W. W. Leontief. Input-output economics. Oxford University Press, USA, 1986.

E. Llera, S. Scarpellini, A. Aranda, and I. Zabalza. Forecasting job creation from renewable energy deployment through a value-chain approach. Renewable and Sustainable Energy Reviews, 21:262-271, 2013.

R. Madlener and M. Koller. Economic and CO2 mitigation impacts of promoting biomass heating systems: an input-output study for vorarlberg, Austria. Energy Policy, 35: 6021-6035, 2007.

M. Markaki, A. Belegri-Roboli, P. Michaelides, S. Mirasgedis, and D. P. Lalas. The impact of clean energy investments on the Greek economy: an input-output analysis (2010 2020). Energy Policy, 57:263-275, 2013.

MEDDE. Énergies marines renouvelables : Étude méthodologique des impacts environnementaux et socio-économiques, 2012b. Ministère de l'Écologie, du Développement durable et de l'Énergie (MEDDE). 361 p.

MEDDE. Premier appel d'offres éolien en mer, 2014. URL http://www.developpementdurable.gouv.fr/6-avril-2012-Designation-des.html_[Accessed_October_10, _2014]. Ministère de l'Écologie du Développement Durable et de l'Énergie (MEDDE).

MEEDM. Plan d'action national en faveur des énergies renouvelables (période 2009 - 2020). Ministère de l'Écologie, de l'Énergie, du Dévelopement durable et de la Mer, 2010. URL WWW.developpement-durable.gouv.fr_[Accessed_October_06,_2014]. 120 p.

MERiFIC. Présentation stratégique de France Énergies Marines. Technopôle Brest-Iroise \& Cornwall Marine Network for the MERiFIC Project, 2013a. 79 p.

R. E. Miller and P. D. Blair. Input-Output Analysis: Foundations and Extensions. Number 978-0-521-51713-3 (ISBN). Cambridge University Press, second edition, 2009.

F. Moisan and A. Chêne. Maîtrise de l'énergie et développement des énergies renouvelables : état des lieux des marchés et des emplois, 2008. URL http://www.ademe.fr/ _[Accessed_December_23,_2014]. ADEME\&Vous. Stratégie \& Études, n 34.

B. Moreno and A. J. Lopez. The effect of renewable energy on employment. The case of Asturias (Spain). Renewable and Sustainable Energy Reviews, 12:732-751, 2008.

K. Mukhopadhyay and P. J. Thomassin. Macroeconomic effects of the ethanol biofuel sector in Canada. Biomass and Bioenergy, 35(7):2822-2838, 2011.

M. Musial and B. Ram. Large-scale offshore wind power in the United States sassessment of opportunities and barriers, 2010. URL http://www.nrel.gov/wind/pdfs/40745.pdf . _[Accessed_November_03,_2014]. National renewable energy laboratory report. 
901 F. Neuwahl, A. Löschel, I. Mongelli, and L. Delgado. Employment impacts of EU biofuels policy: combining bottom-up technology information and sectoral market simulations in an input-output framework. Ecological Economics, 68(1-2):447-460, 2008.

904 C. Oliveira, D. Coelho, P. Pereira Da Silva, and C. H. Antunes. How many jobs can the 905 RES-E sectors generate in the Portuguese context? Renewable and Sustainable Energy 906 Reviews, 21:444-455, 2013.

907 Ouest France. Saint Brieuc. Soixante deux éoliennes offshore de 8 MW, 2014. URL http: eoliennes-offshore-8-mw-10-07-2014-153154_[Accessed_October_08,_2014].

910 Oxford Economics. Analysis of the employment effects of the operation and maintenance 911 a of offshore wind parks in the UK, 2010. URL www.oxfordeconomics.com_[Accessed_ 912 October_08,_2014]. A Report for Vestas Offshore.

913 M. Pedden. Economic impacts of wind applications in rural communities, 2005. URL www.nrel.gov/docs/fy06osti/39099.pdf_[Accessed_December_23,_2014]. NREL Technical Monitor: Flowers, L. Subcontract Report NREL/SR-500-39099.

W. Pfaffenberger, K. Jahn, and M. Djourdjin. Renewable energies: environmental benefits, economic growth and job creation. Case study paper, 2006. Bremer Energie Institut.

918 Germany.

R. Pollin, H. Garrett-Peltier, J. Heintz, and H. Scharber. Green recovery: a program to create good jobs and start building a low-carbon economy, 2008. Department of Economics and Political Economy Research Institute (PERI), University of Massachusetts - Amherst. 42 p.

RIH. Pour un développement durable des activités maritimes et des territoires maritimes. Juin 2011. URL http://rih-lehavre.com/upload/RIH_ACTES_2011_FR.zip. Les Rencontres Internationales du Havre (RIH). 62 p.

J. I. Round. An interregional input-output approach to the evaluation of nonsurvey methods. Journal of Regional Science, 18:179-194, 1978.

E. Sastresa, A. Usón, I. Bribián, and S. Scarpelleni. Local impact of renewables on employment: assessment methodology and case study. Renewable and Sustainable Energy Reviews, 14:679-690, 2010.

H. Schuman and P. Stanley. Questions 85 answers in attitude surveys: experiments on question form, wording, and context. Reprint edition, 1996. Thousand Oaks, CA: SAGE Publications.

934 Scottish Entreprise. A guide to offshore wind and oil \& gas capability, 2011. URL

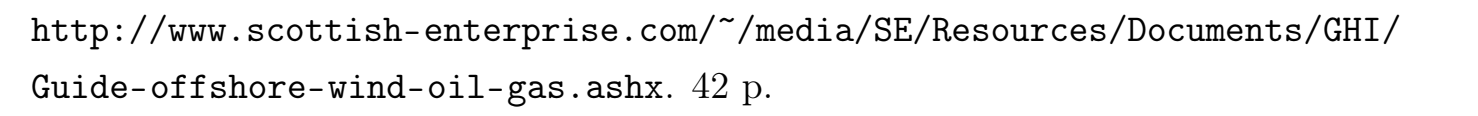


K. Sercy, R. T. Carey, and E. W. Seltzman. South Carolina offshore wind economic I impact study - Phase 2, 2014. URL http://sti.clemson.edu/reports/cat_view/293regional-economic-analysis-laboratory_[Accessed_October_17,_2014]. Coastal Conservation League. Clemson-Strom Thurmond Institute.

M. Simas and S. Pacca. Assessing employment in renewable energy technologies: a case study for wind power in Brazil. Renewable and Sustainable Energy Reviews, 31:83-90, 2014

M. C. Slattery, E. Lantz, and B. L. Johnson. State and local economic impacts from wind energy projects: Texas case study. Energy Policy, 39:7930-7940, 2011.

B. Snyder and M. J. Kaiser. Ecological and economic cost-benefit analysis of offshore wind energy. Renewable Energy, 34(6):1567-1578, 2009.

Solar Foundation. National solar jobs census 2010: a review of the US solar 1. workforce, 2010. URL http://thesolarfoundation.org/research/national-solarjobs-census_[Accessed_December_23,_2014].

X. Sun, D. Huang, and G. Wu. The current state of offshore wind energy technology development. Energy, 41:298-312, 2012.

P. Thornleya, J. Rogersb, and Y. Huang. Quantification of employment from biomass power plants. Renewable Energy, 33:1922-1927, 2008.

T. Tohmo. New developments in the use of location quotients to estimate regional inputoutput coefficients and multipliers. Regional Studies, 38:43-54, 2004.

C. Tourkolias and S. Mirasgedis. Quantification and monetization of employment benefits associated with renewable energy technologies in Greece. Renewable and Sustainable Energy Reviews, 15(6):2876-2886, 2011.

US DE. Potential economic impacts from offshore wind in the Southeast region, 2013. URL wind.energy.gov/_[Accessed_October_16,_2014]. US Departement of Energy. Energy Efficiency \& Renewable Energies. DOE/GO-102013-3858.

C. Wang, W. Zhang, W. Cai, and X. Xie. Employment impacts of CDM projects in China's power sector. Energy Policy, 59:481-491, 2013.

M. Wei, S. Patadia, and D. Kammen. Putting renewables and energy efficiency to work: how many jobs can the clean energy industry generate in the US. Energy Policy, 38(2): 919-931, 2010.

H. F. Weisberg, J. A. Krosnick, and B. D. Bowen. An introduction to survey research, polling, and data analysis. Third edition, 1996. Thousand Oaks, CA: SAGE Publications.

R. Wiser, K. Jenni, J. Seel, E. Baker, M. Hand, E. Lantz, and A. Smith. Expert elicitation survey on future wind energy costs. Nature Energy, 1(DOI: 10.1038/NENERGY.2016.135):1-8, 2016. 
973 D. Zammit and J. Miles. Potential economic impacts from offshore wind in the United 974 States - The Southeast region. Applying the offshore JEDI model to estimate eco975 nomic impacts of potential offshore wind farms along the South Atlantic coast, 2013.

976 URL http://www.windsystemsmag.com/article/detail/548/potential-economic-

977 impacts-from-offshore-wind-in-the-united-states--the-southeast-region/

978 - [Accessed_October_16,_2014].

979 Z. X. Zhang and H. Folmer. Economic modelling approaches to cost estimates for the 980 control of carbon dioxide emissions. Economic Economics, 20:101-120, 1998. 